TAPROBANICA, ISSN 1800-427X. May, 2020. Vol. 09, No. 01: pp. 103-119, pls. 37-42. (C) Research Center for Climate Change, University of Indonesia, Depok, Indonesia www.taprobanica.org

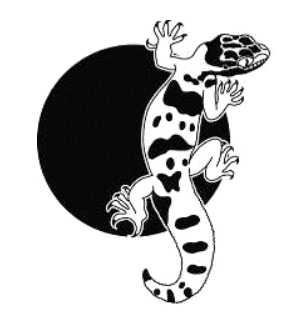

urn:Isid:zoobank.org:act:625B7ED6-E8E3-447B-8246-D02EF4BF24E1

\title{
A NEW SPECIES OF Lankascincus GREER, 1991 (REPTILIA: SCINCIDAE) WITH AN OVERVIEW OF THE L. gansi GROUP
}

\author{
A. Suneth Kanishka ${ }^{1}$, A. Dineth Danushka ${ }^{1} \&$ A.A. Thasun Amarasinghe $e^{2,3}$ \\ ${ }^{1}$ Nature Explorations \& Education Team, No: B-1 / G-6, De Soysapura Flats, Moratuwa 10400, Sri Lanka \\ ${ }^{2}$ Research Center for Climate Change, University of Indonesia, Gd. PAU Lt. 8.5, Kampus UI, Depok 16424, \\ Indonesia \\ ${ }^{3}$ Association of Asian Herpetology (Asosiasi Herpetologi Asia), Jl. BSD Bintaro No. 88, Pondok Aren 15228, \\ Tangerang Selatan, Indonesia \\ ${ }^{2}$ Corresponding author. E-mail: thasun@rccc.ui.ac.id
}

\begin{abstract}
Lankascincus gansi has been considered as a widespread single species, distributed in the wet bioclimatic zone of Sri Lanka (alt. below 1, $100 \mathrm{~m}$ a.s.l.). After a thorough comparison of morphology and morphometry, we recognised two distinct populations from (i) high-elevations (1,000 m a.s.l.) of the Rakwana Hills and (ii) the south-western lowland wet zone [mid-elevations (200-500 m a.s.l.) of the western slopes of the central highlands and the southwestern lowland (0-300 $\mathrm{m}$ a.s.1.)]. These are sufficiently different from one another that we restrict the name $L$. gansi to the lowland rainforest population, and assign a new name to the Rakwana Hills population. We provide a comprehensive redescription for L. gansi based on three topotypes collected from Udugama, Sri Lanka. Considering the lack of morphological distinctiveness and biogeographical isolation we here synonymise L. greeri with L. deignani. A key to the species of the genus Lankascincus is provided.
\end{abstract}

Keywords: Central highlands, mid-elevation, rainforest, South Asia, systematics, taxonomy

\section{Introduction}

The Sri Lankan endemic genus Lankascincus Greer, 1991 was erected to encompass most Sri Lankan species of small skinks of the genus Sphenomorphus Fitzinger, 1843. Currently 10 species are known (Batuwita 2019, Wickramasinghe et al. 2020) from the island.

Lankascincus gansi was first described by Greer (1991) based on specimens collected from the lower Rakwana Hills at an elevation range of
0-300 $\mathrm{m}$ a.s.1. This species has long been considered to be a widely distributed species in the wet zone (alt. 0-1,100 $\mathrm{m}$ a.s.l.), and was recently identified as a species complex, the $L$. gansi group. The members of this group can be easily distinguished by other Lankascincus by being smaller bodied (SVL 30.0-37.0 mm), and further differ by having a combination of characters such as prefrontals in contact, two primary temporals, paired frontoparietals, last 
supralabial longitudinally split, and second supraocular wider in transverse axis (fide Batuwita 2019).

Batuwita (2019) considered Lankascincus gansi as a widespread single species, distributed throughout the wet zone. After a thorough comparison of morphology and morphometry, we are confident enough to recognise two distinct populations, one in high-elevations $(1,000 \mathrm{~m}$ a.s.1.) of the Rakwana Hills and one in the low elevations of the wet zone including mid elevations of the Central highlands $(200-500 \mathrm{~m}$ a.s.1.), and the lowland wet zone $(0-300 \mathrm{~m}$ a.s.1.). We restrict the name $L$. gansi - which was described from Udugama (alt. $165 \mathrm{~m}$ a.s.1.) to the south-western lowland population, and recognize the remaining population as a distinct species, to which we assign a new name. Among the lowland populations of true L. gansi, the sub population occurring in the mid-elevations of the Central highlands (200-500 m a.s.l.) shows slightly discrete morphological characters and probably represents another distinct species. We treat this here as Lankascincus cf. gansi until this issue is resolved by integrated taxonomic approaches.

\section{Material and methods}

Data collection. Specimens were examined in the collections of the Natural History Museum, London, UK (BMNH); National Museum of Sri Lanka, Colombo, Sri Lanka (NMSL); and Wildlife Heritage Trust, Sri Lanka (WHT), currently deposited at NMSL. Museum acronyms follow Uetz et al. (2019). Morphometric and meristic data for species comparisons were obtained from examined specimens (see Appendix I). Natural history data were taken from our own field observations; notes made during the last ten years, as well as published literature.

Morphometric and meristic data. Observations were made using a Leica M50 $(\times 10-40)$ microscope, on the left side of the specimens. The following measurements were taken to the nearest $0.1 \mathrm{~mm}$ with a Mitutoyo digital calliper (each measurement was taken three times and the mean recorded): snout-vent length (SVL, from tip of snout to anterior margin of vent), head length (HL, from posterior edge of the retro-articular process of the mandible to tip of snout), head width (HW, width of head at the temporo-mandibular articulation / angle of the jaws), head depth (HD, dorso-ventral distance between occiput and throat), snout length (ES, from anterior border of orbit to tip of snout), orbit diameter (ED, the greatest horizontal diameter of the orbit), tympanum-eye length (TYE, from posterior border of orbit to anterior border of tympanum), interorbital width (IO, shortest distance between dorso-medial margins of orbits), brachium length (UAL, on the dorsal surface from the axilla to the inflection of the flexed elbow), antebrachium length (LAL, on the dorsal surface from the posterior surface of the elbow while flexed 90 degree to the base of the heel), palm length [from wrist (carpus) to distal tip of longest finger], thigh length (FEL, from the anterior margin of the hind limb at its insertion point on the body to the knee while flexed), shank length (TBL, from the posterior surface of the knee while flexed to the base of the heel), foot length (FOL, from heel to tip of longest toe), body width (BW, greatest width at midbody), body depth (BD, greatest depth at midbody), axilla-groin length ( $\mathrm{AG}$, distance between axilla and groin), tail base width (TBW, greatest width at tail base), tail length (TL, from tip of tail to posterior margin of vent), and total length $(\mathrm{TOL}=\mathrm{SVL}+\mathrm{TL}$, from tip of snout to tip of tail).

Supralabial (SUP) and infralabial (INF) scales were counted from the gape to the rostral and mental scales, respectively. Ventrals included all scales from the scale posterior to the postmental to the last scale bordering the vent, counted along the ventral midline; and subcaudals from the first scale bordering the vent up to the tail tip, counted along the subcaudal midline. Paravertebral scales were counted from the postparietal/nuchal to the level of the posterior margin of the thigh in a straight line immediately left of the vertebral column. Subdigital lamellae were counted from the first proximal enlarged lamella wider than the largest palm scale to the distal-most lamella at the base of the claw. Total number of longitudinal scale rows was counted around the midbody (AG/2, at half-length of axilla-groin length). Sex was determined by the throat colouration, and the presence or absence of hemipenes by illuminating the base of the tail using hand torches.

Morphometric analyses. We conducted a principal component analysis (PCA) to examine patterns of morphometric variation of the Lankascincus gansi group. A series of components, exceeding $80 \%$ of eigenvalues as a whole, were taken into account when inspecting 
the ordination. The principal axis method was used to extract the components followed by an orthogonal rotation. Only adult male specimens were included in this analysis, using the following five measurements normalized to the ratios: TL/SVL, HL/TOL, FOL/SVL, FOL/TBL, and $\mathrm{BD} / \mathrm{AG}$. Prior to the ordination, those measurements were standardized by scaling them to a standard deviation of 1.0, and mean of 0.0. In the PCA, the majority of variation was captured by the first component (Table 1). All analyses were performed in the statistical $\begin{array}{llll}\text { software environment } \quad \mathrm{R}, & \mathrm{v} 2.15 .0 \quad(R\end{array}$ Development Core Team, 2012).

Table 1. Factor loadings for the first four principal components (PC) of morphometric characters in $L$. gansi, $L$. cf. gansi, and the new species. See text for definitions of character abbreviations.

\begin{tabular}{lrccc}
\hline Character & \multicolumn{1}{c}{ PC1 } & PC2 & PC3 & PC4 \\
\cline { 2 - 5 } TL/SVL & 0.9773 & 0.1968 & 0.0708 & 0.0026 \\
HL/TOL & -0.0420 & -0.0065 & 0.1476 & -0.0612 \\
FOL/SVL & -0.0449 & 0.1340 & 0.1979 & 0.9695 \\
FOL/TBL & -0.1822 & 0.9630 & -0.1656 & -0.1083 \\
BD/AG & -0.0885 & 0.1260 & 0.9522 & -0.2110 \\
Eigenvalue & 0.0291 & 0.0047 & 0.0006 & 0.0000 \\
$\begin{array}{l}\text { Proportion } \\
\text { of variance }\end{array}$ & 84.461 & 13.524 & 1.8268 & 0.1379 \\
\hline
\end{tabular}

\section{Results}

Morphometric analyses. We retained the first three components for the inspection of PCA results (Fig. 1), since they include the first two principal components covering more than $97 \%$ of the variance. The eigenvalues were allocated $84.5 \%, 13.5 \%$, and $1.8 \%$ on component 1,2 , and 3 , respectively (Table 1 ).

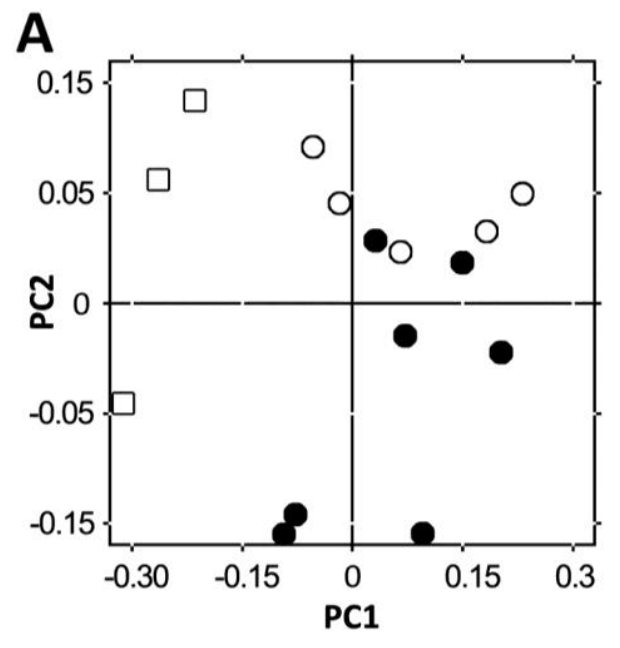

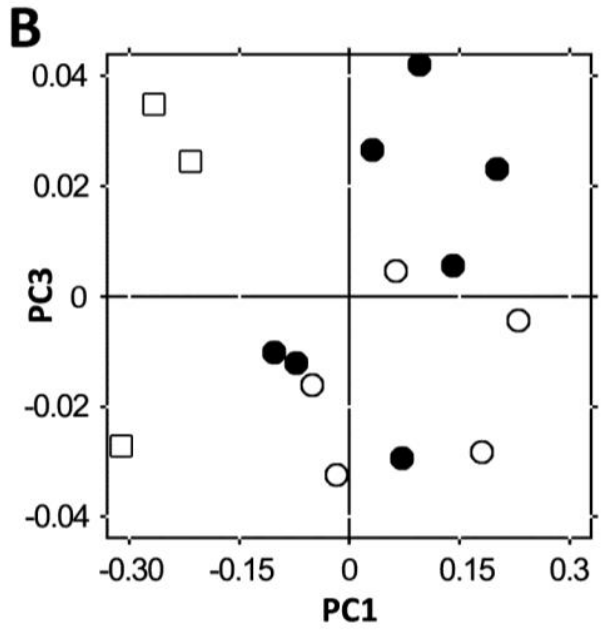

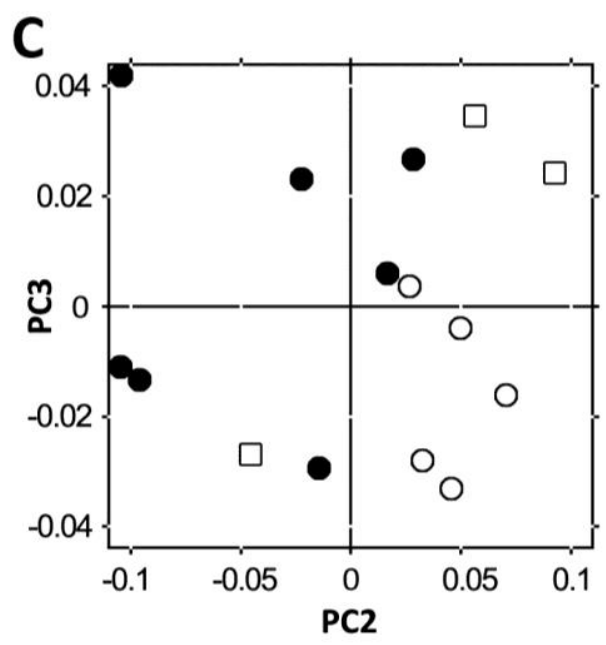

Figure 1. Morphometric analysis of L. gansi (filled circles), the new species from Rakwana Hills (open circles) and $L$. cf. gansi from lower Central highlands (open squares): PC1 vs. PC2; (B) PC1 vs. PC3; (C) PC2 vs. PC3.

The first axis was highly correlated with TL/SVL (loading value: 0.98) among the five measurements. The second axis was characterized mostly by FOL/TBL (0.96). The third axis was dominated by BD/AG (0.95) exclusively. All specimens of the new species are distinctively distributed along the first, second and third axes from ten Lankascincus gansi specimens (seven from the lowland wet zone and three from the lower central highlands) and five specimens from the new species from Rakwana Hills. The fourth axis did not reveal any particular pattern among groups. According to PCA spatial distribution, the Lankascincus cf. gansi from lower Central highlands is characterized by relatively shorter tail, longer foot, robust and shortened body compared to $L$. gansi and the new species from Rakwana Hills. Moreover, the new species tends to have a 
longer tail and slim elongate bodies relative to $L$. cf. gansi from the lower Central highlands, and longer foot relative to $L$. gansi.

\section{Taxonomy}

Based on the morphology we have identified distinct species-groups within the genus Lankascincus: L. gansi group: L. gansi sensu lato; L. taylori group: L. taylori Greer, 1991 and L. sripadensis Wickramasinghe, Rodrigo, Dayawansa et al., 2007; L. dorsicatenatus group: L. dorsicatenatus (Deraniyagala, 1953), L. megalops (Annandale, 1906); L. deignani group: L. deignani (Taylor, 1950) and L. greeri Batuwita \& Pethiyagoda, 2007; and L. fallax (Peters, 1860), L. taprobanensis (Kelaart, 1854), and $L$ merrill Wickramasinghe, Vidanapathirana \& Wickramasinghe, 2020 as individual species.

Among these species-groups and individual species, the $L$. gansi group is clearly distinguished by having prefrontals in contact (vs separated in L. taprobanensis); two primary temporals ( $v s$ single in $L$. taylori group, $L$. deignani group, and L. taprobanensis); paired frontoparietals ( $v s$ fused in $L$. fallax); last supralabial longitudinally split ( $v s$ single in $L$. taylori group, $L$. deignani group, $L$. fallax and $L$. taprobanensis); second supraocular wider in transverse axis ( $v s$ subequal in $L$. dorsicatenatus group, L. deignani group, and L. fallax and $L$. taprobanensis). The recently described $L$. merrill shares characters of both the gansi group and L. fallax group. Based on the above characters, the new species we describe herein is clearly placed within the $L$. gansi group, thus we compared it thoroughly with its congener, $L$. gansi. It is also compared with L. merrill, as it shares characters of L. gansi group.

\section{Lankascincus gansi Greer, 1991}

(Figs. 1-3, 8, Tables 1-6)

Lankascincus gansi Greer, 1991 [Partim]

Lankascincus gansi - Batuwita 2019 [Partim]

Holotype. Adult male, CM 67932, SVL 34.0, collected from Udugama $\left(06^{\circ} 13^{\prime} \mathrm{N}, 80^{\circ} 20^{\prime} \mathrm{E}\right.$, alt. $165 \mathrm{~m}$ a.s.1.), near Deniyaya, Galle District, Southern Province, Ceylon (=Sri Lanka), by L. Jayawickrama, on 24 March 1977 [not examined].

Other specimens $(n=11)$. Adult males, NMSL 0397-SB, SVL $30.0 \mathrm{~mm}$, collected from Udugama $\left(6^{\circ} 13^{\prime} \mathrm{N}, 80^{\circ} 20^{\prime} \mathrm{E}\right.$, alt. $100 \mathrm{~m}$ a.s.l), Galle, Southern Province, by S. Batuwita; WHT
6664, SVL $34.3 \mathrm{~mm}$, collected from Dediyagala Forest Reserve near Udugama $\left(6^{\circ} 14^{\prime} \mathrm{N}, 80^{\circ} 20^{\prime}\right.$ E), alt. $100 \mathrm{~m}$ a.s.l), Southern Province, by K. Wewelwala \& M.M Bopage; Adult female, WHT 6670, SVL $32.9 \mathrm{~mm}$, collected from Kanneliya Forest Reserve near Udugama $\left(6^{\circ} 14\right.$ N, $80^{\circ} 20^{\prime}$ E, alt $100 \mathrm{~m}$ a.s.l), Southern Province By B.A.S. Greshana \& A.I. Alagiyawadu, on 03 July 1999; see other non-topotypic specimens listed in Appendix I.

Diagnosis. Lankascincus gansi is distinguished from its congeners by possessing the following combination of characters: maximum SVL 30.0 $\mathrm{mm}$ and $34.3 \mathrm{~mm}$; prefrontals in contact, two primary temporals, upper primary temporal juxtaposed with secondary temporals, paired frontoparietals, second supraocular wider in transverse axis, frontal shorter than the length of frontoparietals and interparietal combined, throat scales cycloid and imbricate, seven supralabials with last one split, five infralabials, 24 midbody scale rows, 46-48 paravertebrals, 46-48 ventrals, 8 and $12-15$ lamellae on fourth finger and toe respectively, pinkish yellow venter, dark grayish brown throat with white flecks on labials, lower temporal region, throat, and neck spread until shoulders, brown (darker than venter) neck; the differences are summarized in Tables 2-5.

Description of topotype. Characters of one of the topotypes is followed, when appropriate, by those of the other two topotypes in parenthesis. Male, NMSL 0397-SB (male WHT 6664, female WHT 6670), SVL $30.0 \mathrm{~mm}(34.3 \mathrm{~mm}$, $33.7 \mathrm{~mm})$. Head moderately large, HL $21.6 \%$ of SVL $(21.3,21.3)$, narrow, HW $66.1 \%$ of HL (54.8, 61.4), HW $14.3 \%$ of SVL $(11.7,13.1)$, indistinct from neck; snout short, ES 35.4\% of HL, shorter than orbit diameter, ES $88.5 .0 \%$ of $\mathrm{ED}$, slightly convex in lateral profile.

Rostral shield large, posterior margin convex; nasal non-fused, nostril large, no supranasal or postnasal scale; frontonasal larger than prefrontals, in contact with anterior loreal laterally; prefrontals broadly (narrowly) in contact each other, in contact with anterior and posterior loreals laterally, $1^{\text {st }}$ supraciliary, $1^{\text {st }}$ supraocular and frontal posteriorly; frontal longer than frontonasal and prefrontal combined, shorter than frontoparietal and interparietal length combined; supraoculars four, $2^{\text {nd }}$ widest in transverse axis, $1^{\text {st }}$ longest in longitudinal axis, first two supraoculars in contact with 


\section{Plate 37}

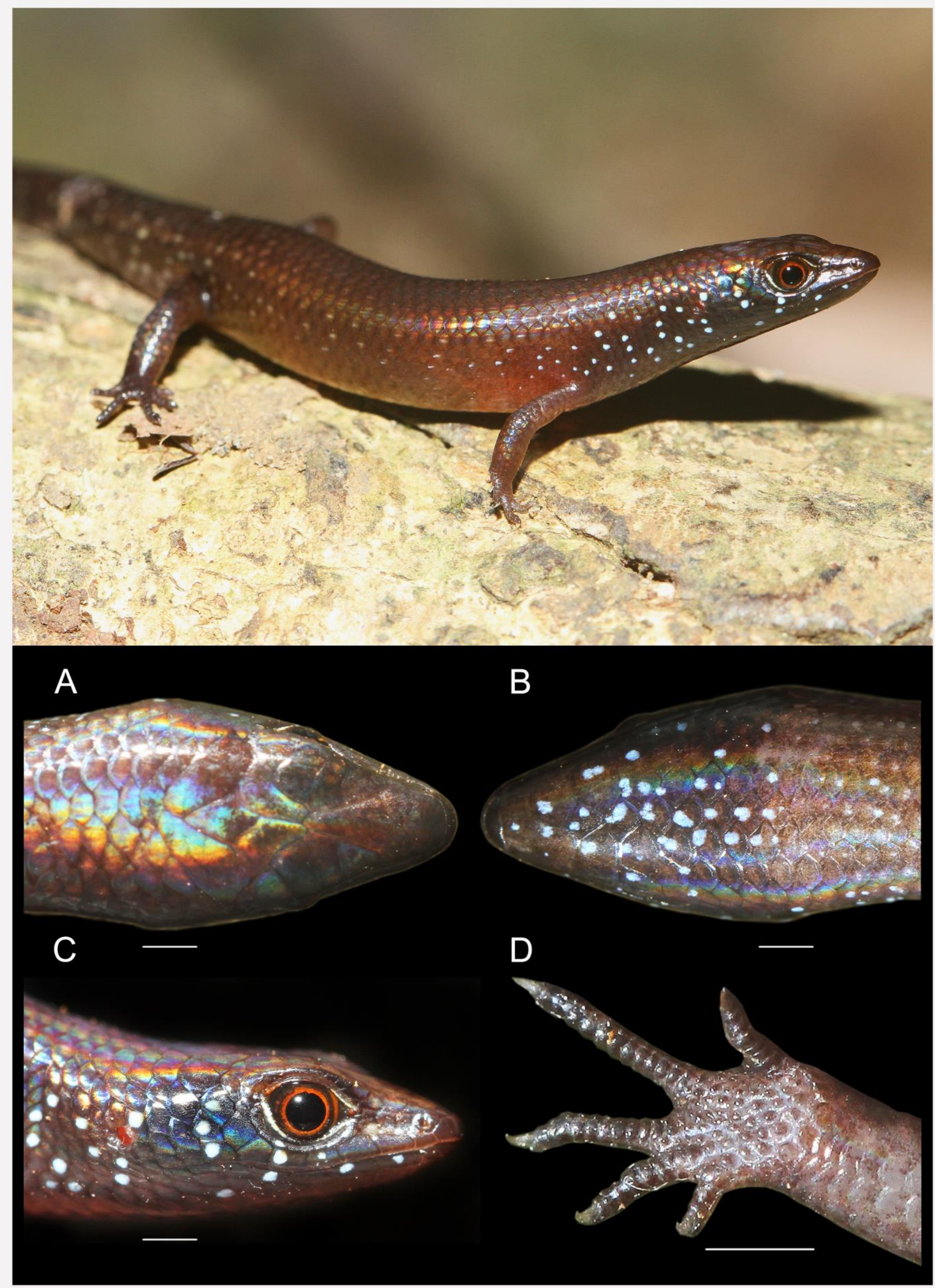

Figure 2. Lankascincus gansi, a breeding male (not collected) from Udugama (type locality) in the south-western lowland wet zone of Sri Lanka (SVL $32.3 \mathrm{~mm}$ ); head in (A) dorsal view, (B) ventral view, (C) lateral view, and (D) ventral side of the foot (scale: $1 \mathrm{~mm}$ ). 


\section{Plate 38}

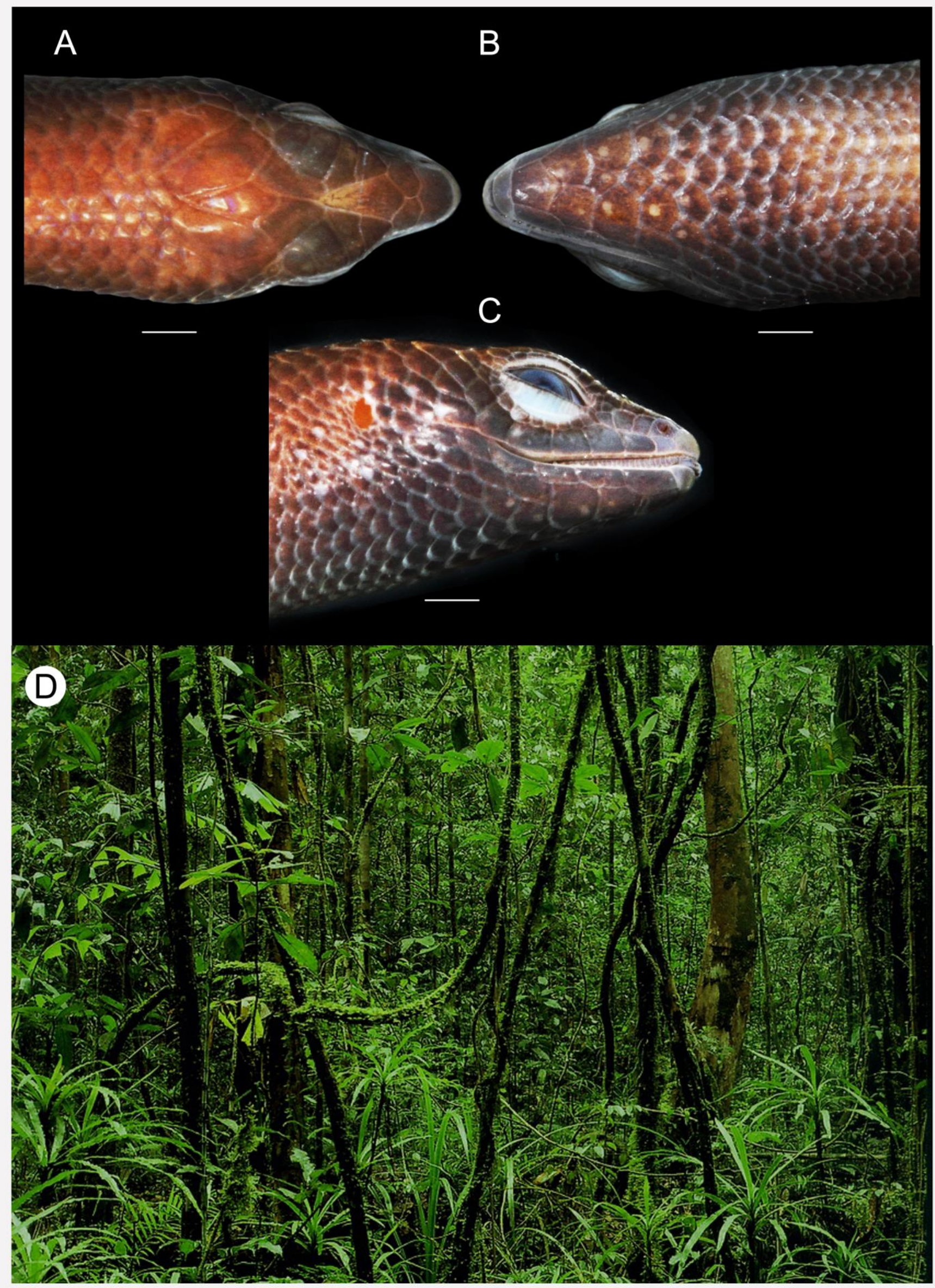

Figure 3. Lankascincus gansi, a breeding male (NMSL 0397-SB), from Udugama (type locality), SVL $30.0 \mathrm{~mm}$, head in (A) dorsal view, (B) ventral view, (C) lateral view (scale $1 \mathrm{~mm}$ ); and (D) the habitat near the type locality: the south-western lowalnd rain forests of Sri Lanka. Photo C V. Weeratunge. 
frontal, $3^{\text {rd }}$ in contact with frontoparietal, $4^{\text {th }}$ in contact with frontoparietal, parietal, upper pretemporal and last supraciliaries; frontoparietals paired, larger than interparietal, in contact with $2^{\text {nd }}-4^{\text {th }}$ supraoculars; parietals large, touching each other behind interparietal, in contact with $4^{\text {th }}$ supraocular and upper pretemporal anteriorly, upper secondary temporal and body scales laterally; loreals two, anterior loreal touching prefrontal, frontonasal, nasal, $2^{\text {nd }}$ supralabial, and posterior loreal; posterior loreal larger than anterior loreal, touching prefrontal, anterior loreal, $2^{\text {nd }}$ and $3^{\text {rd }}$ supralabials, two preoculars, and $1^{\text {st }}$ supraciliary; preoculars two, lower preocular larger, touching upper preocular, posterior loreal, $3^{\text {rd }}$ supralabial and palpebral scales; eye large, ED $40.0 \%$ of $\mathrm{HL}$, orbit diameter same as tympanum-eye length, ED $100.0 \%$ of TYE, pupil rounded; interorbital distance broad, IO $6.9 \%$ of HW; supraciliaries ten (nine, ten), placed between supraocular and upper palpebrals; upper palpebrals 14, placed between eye and supraciliary row; lower palpebrals 15 , placed between eye and subocular row; suboculars nine, smaller than supralabials, touching $3^{\text {rd }}-6^{\text {th }}$ supralabials ventrally, lower postoculars, primary temporals, and lower pretemporal scale posteriorly; last subocular touching lower and upper primary temporal, lower pretemporal, lower anterior and posterior postoculars; anterior postoculars two, upper one larger than lower; posterior postoculars two, subequal to anterior postoculars in size, touching pretemporals; pretemporals two, lower pretemporal larger than upper, touching parietals, upper primary temporal and upper secondary temporals; primary temporals two, upper one larger and juxtaposed with secondary temporals; lower primary temporal touching $7^{\text {th }}-9^{\text {th }}$ suboculars, $6^{\text {th }}$ and $7^{\text {th }}$ supralabials; upper primary temporal touching last upper-supralabial, and upper and lower secondary temporals; secondary temporals two, upper one larger than the lower, upper one touching parietal and upper tertiary temporal; tertiary temporals three, upper one larger, touching lower secondary temporal and upper posterior supralabial.

Supralabials 7 , the last supralabial split, $5^{\text {th }}$ at mid-orbit point; post-supralabials two; mental wider than postmental in transverse axis, shorter in longitudinal axis, touching $1^{\text {st }}$ infralabial only; infralabials five, single post-infralabial; chinshields three pairs, first pair meeting in midline, first chinshield touching $1^{\text {st }}$ and $2^{\text {nd }}$ infralabials, second pair touching $2^{\text {nd }}$ and $3^{\text {rd }}$ infralabials; gular scales cycloid, imbricate.

Body moderately elongate, dorsal scales smooth, cycloid; paravertebrals $46(46,48) ; 24$ transverse scale rows at mid-body; ventrals 46 $(48,46)$, smooth, imbricate; median precloacals enlarged; Forelimbs short, hind limbs relatively long, LAL $47.0 \%$ of TBL $(58.3,50.3)$; thigh short and $76.5 \%$ of shank length; fourth finger with nine smooth lamellae; fourth toe with 14 smooth lamellae; lamellae formulae for fingers and toes $4>3>5>2>1$ and $4>3>5>2>1$, scales of palm and sole elevated.

Tail original, complete, longer than body (TL $121.0 \%$ of SVL), round in cross section.

Variation. See Tables 1 and 2.

Colouration. In preservative, dorsal surface of the head, body, limbs, and tail uniform chestnut brown, anterior dorsal head darker; lower parts of the lateral head, temporal region, and throat grayish brown; neck dark brown; lateral body yellowish brown; white flecks present on labials, lower temporal region, throat, and neck; venter cream.

In life (based on live breeding males), dorsum iridescent bronze brown, laterally iridescent reddish brown; hind limbs bronze brown with whitish markings; dorsal head dark brown, anteriorly blackish; lower parts of the lateral head, temporal region, and throat dark grayish brown; neck brown, lighter than throat and darker than venter; white flecks present on labials, lower temporal region, throat, and neck spread until shoulders; venter pinkish yellow, ventral side of the limbs gray.

Comparison. See Tables 4 and 5.

Natural history. A diurnal skink active mostly at $25-32{ }^{\circ} \mathrm{C}$. This is a lowland rainforest dependent species associated with thick leaf litter on the forest floor. Most of the individuals were observed in habitats where the leaf-litter thickness is $15-30 \mathrm{~mm}$ with ground temperatures of $25-30{ }^{\circ} \mathrm{C}$. Animals were also found under rocks and fallen logs. This species prefers shady habitats with high canopy cover of 85-95\%. This species is sympatric with Lankascincus greeri (fide Batuwita 2019), L. dorsicatenatus, and $L$. cf. taylori in most of the localities.

Distribution. This species is restricted to the lowland (alt. $0-300 \mathrm{~m}$ a.s.l.) tropical rainforests in the wet zone of southwestern Sri Lanka. See the map (Fig. 8) for confirmed locality data based on museum specimens and personal observations. 
Lankascincus sameerai sp. nov.

(Figs. 1, 4, 5, 8, Tables 1-6)

Lankascincus gansi Greer, 1991 [Partim]

Lankascincus gansi - Batuwita 2019 [Partim]

Holotype. Adult male, WHT 6720, SVL 36.0 $\mathrm{mm}$, collected from Morningside $\left(6^{\circ} 24^{\prime} \mathrm{N}\right.$, $80^{\circ} 36^{\prime} \mathrm{E}$, alt. $1000 \mathrm{~m}$ a.s.1.), Matara District, Southern Province, Sri Lanka, by M.M. Bahir \& S. Nanayakkara, on 14 January 1999.

Paratypes $(\boldsymbol{n}=5)$. Adult males, WHT 1608, SVL $36.8 \mathrm{~mm}$, collected from Morningside $\left(6^{\circ} 24^{\prime} \mathrm{N}, 80^{\circ} 36^{\prime} \mathrm{E}\right.$, alt. $1000 \mathrm{~m}$ a.s.1.), Matara District, Southern Province, Sri Lanka, by D.E. Gabadage \& M.M. Bahir, on 21 February 1996; WHT 6741, SVL $35.5 \mathrm{~mm}$; WHT 6749a, SVL $35.0 \mathrm{~mm}$; WHT 6749b, SVL $35.0 \mathrm{~mm}$; adult female, WHT 6593, SVL $35.7 \mathrm{~mm}$; collected from Silverkanda, Deniyaya $\left(6^{\circ} 24^{\prime} \mathrm{N}, 80^{\circ} 37^{\prime} \mathrm{E}\right.$, alt. $760 \mathrm{~m}$ a.s.l), Matara District, Southern Province, Sri Lanka.

Diagnosis. Lankascincus sameerai sp. nov. is distinguished from its congeners by possessing the following combination of characters: maximum SVL 35.0-36.8 $\mathrm{mm}$; prefrontals narrowly in contact, two primary temporals, upper primary temporal juxtaposed with secondary temporals, paired frontoparietals, second supraocular wider in transverse axis, frontal length more or less equal with the length of frontoparietals and interparietal combined, throat scales cycloid and imbricate, seven supralabials with last one split, four infralabials, 26 midbody scale rows, 48 paravertebrals, 4648 ventrals, 7-8 and 12-13 lamellae on fourth finger and toe respectively, brownish pink venter, dark gray throat with yellow flecks on labials, lower temporal region until shoulders (no flecks on throat and neck), dark brown (lighter than throat) neck; the differences are summarized in Tables $2-5$.

Description of holotype. Male, SVL $36.0 \mathrm{~mm}$. Head moderately large (HL $20.0 \%$ of SVL), narrow (HW 58.3\% of HL, HW $11.6 \%$ of SVL), indistinct from neck; snout short (ES 27.8\% of HL, ES $47.6 \%$ of HW), shorter than orbit diameter (ES $83.3 \%$ of ED), slightly convex in lateral profile.

Rostral shield large, posterior margin convex; nasal non-fused, nostril large, no supranasal or postnasal scale; frontonasal longer than prefrontals, in contact with anterior loreal laterally; prefrontals narrowly in contact each other, in contact with anterior and posterior loreals laterally, $1^{\text {st }}$ supraciliary, $1^{\text {st }}$ supraocular and frontal posteriorly; frontal longer than frontonasal and prefrontal combined, equal in length with frontoparietal and interparietal combined; supraoculars four, $2^{\text {nd }}$ widest in transverse axis, $1^{\text {st }}$ longest in longitudinal axis, first two supraoculars in contact with frontal, $3^{\text {rd }}$ in contact with frontoparietal, $4^{\text {th }}$ in contact with frontoparietal, parietal, upper pretemporal and last supraciliaries; frontoparietals paired, similar in size with interparietal, in contact with $2^{\text {nd }}-4^{\text {th }}$ supraoculars; parietals large, touching each other behind interparietal, in contact with $4^{\text {th }}$ supraocular and upper pretemporal anteriorly, upper secondary temporal and body scales laterally; loreals two, anterior loreal touching prefrontal, frontonasal, nasal, $2^{\text {nd }}$ supralabial, and posterior loreal; posterior loreal larger than anterior loreal, touching prefrontal, anterior loreal, $2^{\text {nd }}$ supralabial, two preoculars, and $1^{\text {st }}$ supraciliary; preoculars two, lower preocular larger, touching upper preocular, posterior loreal, $2^{\text {nd }}$ and $3^{\text {rd }}$ supralabials, and palpebral scales; eye large (ED 33.3\% of HL), orbit diameter greater than the tympanum-eye length (ED $109.1 \%$ of TYE), pupil rounded; interorbital distance broad (IO $7.1 \%$ of $\mathrm{HW}$ ); supraciliaries nine, placed between supraocular and upper palpebrals; upper palpebrals 15, placed between eye and supraciliary row; lower palpebrals 16, placed between eye and subocular row; suboculars nine, smaller than supralabials, touching $3^{\text {rd }}-6^{\text {th }}$ supralabials ventrally, lower postocular, primary temporals, and lower pretemporal scale posteriorly; last subocular touching lower and upper primary temporals, lower pretemporal, lower anterior and posterior postoculars; anterior postoculars two, upper one smaller than lower; posterior postoculars two, larger than anterior postoculars, touching pretemporals; pretemporals two, subequal, touching parietals, upper primary temporal and upper secondary temporals; primary temporals two, lower one larger and juxtaposed with secondary temporals; lower primary temporal touching $7^{\text {th }}-9^{\text {th }}$ suboculars, $6^{\text {th }}$ and $7^{\text {th }}$ supralabials; upper primary temporal touching last upper-supralabial, and upper and lower secondary temporals; secondary temporals two, upper one larger than the lower, upper one touching parietal and upper tertiary temporal; tertiary temporals three, middle one larger, touching lower secondary temporal and upper posterior supralabial. 


\section{Plate 39}

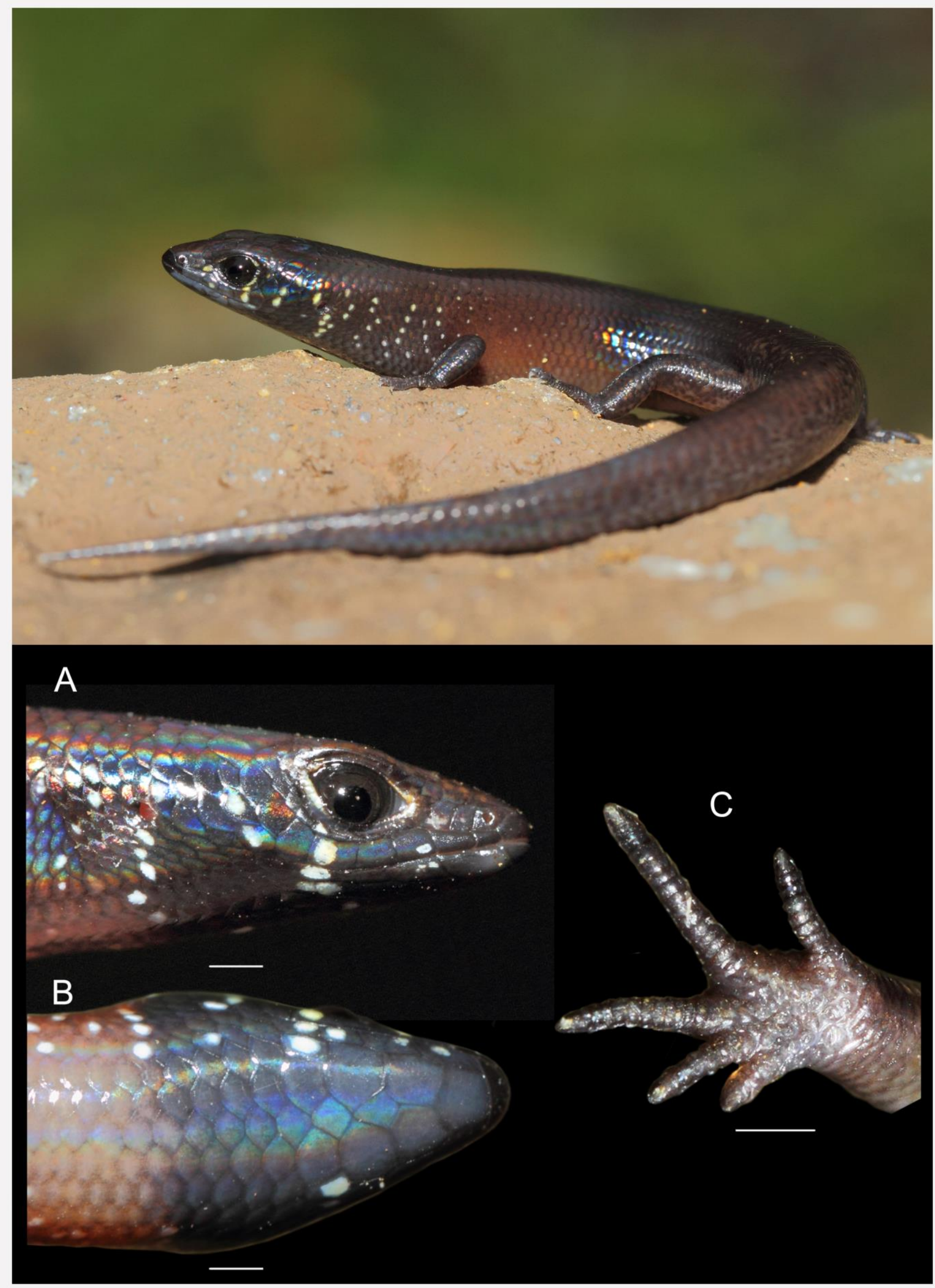

Figure 4. Lankascincus sameerai sp. nov., a breeding male (not collected) from Morningside in the Rakwana Hills of Sri Lanka (SVL $35.0 \mathrm{~mm}$ ); head in (A) lateral view, (B) ventral view, and (C) ventral side of the foot. (scale: $1 \mathrm{~mm}$ ). 


\section{Plate 40}

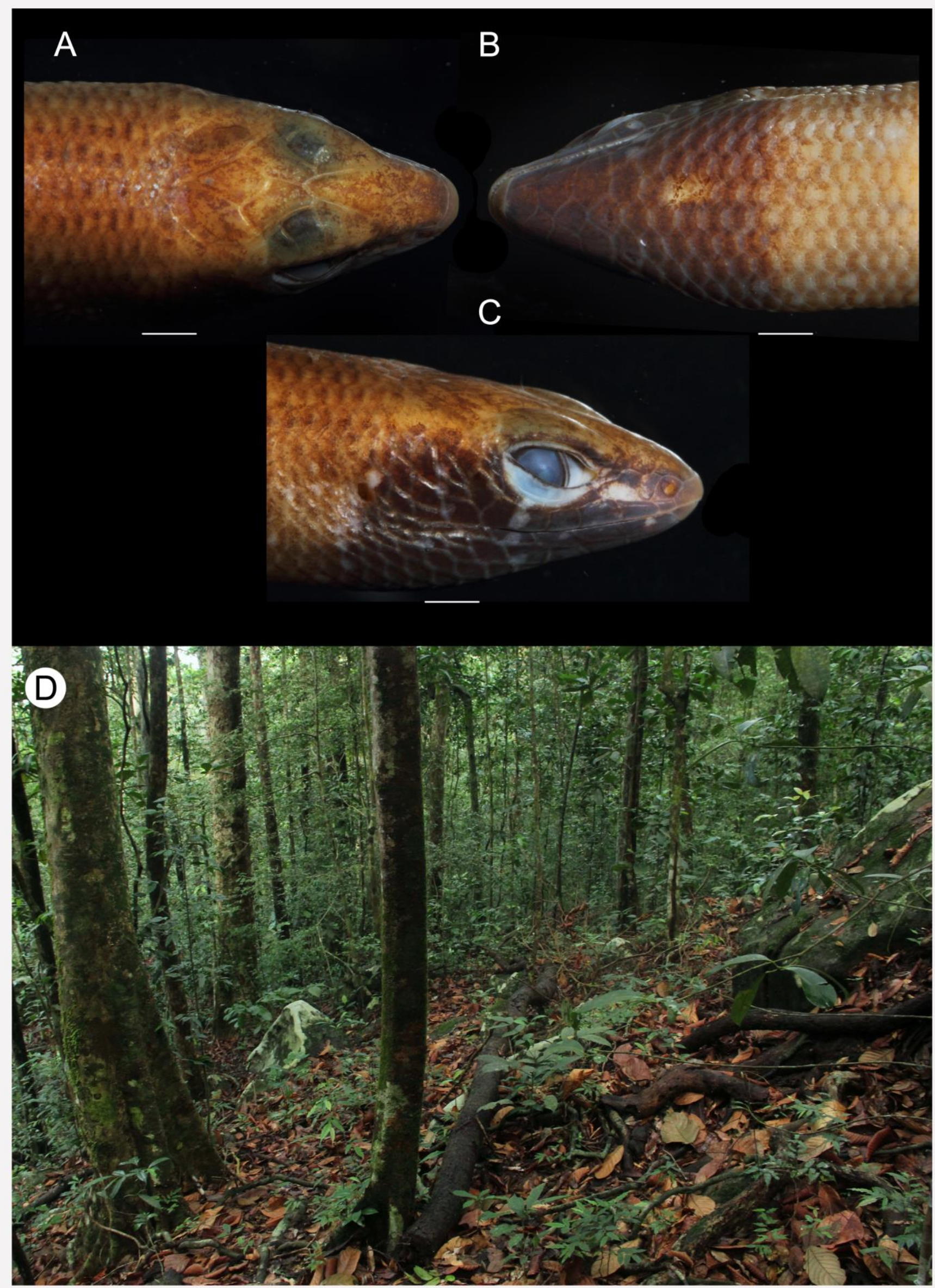

Figure 5. Lankascincus sameerai sp. nov., holotype male (WHT 6720) from Morningside (SVL $36.0 \mathrm{~mm}$ ); head in (A) dorsal view, (B) ventral view, (C) lateral view (scale $1 \mathrm{~mm}$ ); and (D) the habitat of the type locality: submontane forests in Rakwana Hills. Photo C D.M.S. Suranjan Karunarathna. 
Supralabials 7 , the last supralabial split, $5^{\text {th }}$ at mid-orbit point; post-supralabials two; mental wider than postmental in transverse axis, shorter in longitudinal axis, touching $1^{\text {st }}$ infralabial only; infralabials four, single post-infralabial; chinshields three pairs, first pair meeting in midline, first chinshield touching $1^{\text {st }}$ and $2^{\text {nd }}$ infralabials, second pair touching $2^{\text {nd }}$ and $3^{\text {rd }}$ infralabials; gular scales cycloid, imbricate.

Body moderately elongate, dorsal scales smooth, cycloid; paravertebrals 48; 26 transverse scale rows at mid-body; ventrals 48 , smooth, imbricate; median precloacals enlarged; Forelimbs short, hind limbs relatively long, LAL $54.4 \%$ of TBL; thigh short and $73.7 \%$ of shank length; fourth finger with eight smooth lamellae; fourth toe with 13 smooth lamellae; lamellae formulae for fingers and toes $4>3>5>2>1$ and $4>3>5>2>1$, scales of palm and sole elevated.

Tail original, complete, longer than body (TL $119.4 \%$ of SVL), round in cross section.

Variation. See Tables 1-2.

Colouration. In preservative, dorsal surface of the head, body, limbs, and tail uniform brownish yellow, dorsal head lighter; lower parts of the lateral head and temporal region brownish gray, and throat uniform grayish brown; neck uniform pale brown; lateral body pale brownish yellow; white flecks present on labials, lower temporal region (no white flecks on throat and neck); venter creamy white.

In life (based on live breeding males), dorsum dark blackish brown, laterally dark chestnut brown; limbs uniform blackish brown with pale brown markings on hind limb; dorsal head dark blackish brown; lower parts of the lateral head and temporal region dark blackish brown; throat dark gray; neck dark brown, lighter than throat and darker than venter; yellow flecks present on supralabials and lower temporal region spread until shoulders; flecks on infralabials white (no white flecks on throat and neck); venter brownish pink, ventral side of the forelimbs orange, hind limbs gray.

Etymology: The specific epithet is an eponym Latinized in the genitive singular, honouring Sri Lankan herpetologist $\mathrm{Mr}$. Sameera Karunarathna (as D.M.S. Suranjan Karunarathna in publications) to express our sincere appreciation for his remarkable contributions to herpetology, especially the agamid and gekkonid fauna of Sri Lanka. The first two authors of this publication further express their gratitude for his generous teaching and guidance in taxonomic studies. Sameera's remarkable contributions to biodiversity conservation in Sri Lanka, especially the enormous effort in popularizing reptile conservation among the general public, is highly commendable. The senior author of this publication celebrates his research partnership and friendship with Sameera since 2003. Suggested vernacular names are «తిరండో एజిऊิพฺฺ (Sameeragé lak-hikanala) and Sameera's Lanka-skink, in Sinhala and English, respectively.

Comparison. Lankascincus sameerai sp. nov. is most similar to $L$. gansi and $L$. merrill. However, the new species differs from them by characters listed in Table 3.

In addition, among the other similar species, the new species is distinguished from Lankascincus dorsicatenatus and L. megalops by having four infralabials ( $v s$ five), 7 or 8 lamellae on fourth finger ( $v s 9-12), 12$ or 13 lamellae on fourth toe (vs 16-18), $2^{\text {nd }}$ supraocular widest in transverse ( $v s$ longitudinal), a dark dorso-lateral longitudinal stripe absent ( $v$ s present); from L. deignani and L. greeri by having four infralabials ( $v s$ five), 7 or 8 lamellae on fourth finger (vs 11-14), 12 or 13 lamellae on fourth toe (vs 19 or 20), two primary temporals ( $v s$ single), $2^{\text {nd }}$ supraocular widest in transverse ( $v s$ longitudinal), last supralabials longitudinally split ( $v s$ entire), primary temporal juxtaposed with lower secondary temporal ( $v s$ imbricate); from $L$. fallax by having four infralabials ( $v s$ five), ventrals $46-48 \quad(v s \quad 49-58), 2^{\text {nd }}$ supraocular widest in transverse ( $v s$ longitudinal), last supralabials longitudinally split ( $v s$ entire); from L. taprobanensis by having seven infralabials ( $v s$ six), four infralabials ( $v s$ six), paravertebrals 48 (vs 53-63), ventrals 46-48 (vs 59-64), two primary temporals ( $v s$ single), prefrontals in contact ( $v s$ separated), $2^{\text {nd }}$ supraocular widest in transverse ( $v s$ longitudinal), last supralabials longitudinally split ( $v s$ entire), a dark dorsolateral longitudinal stripe absent ( $v s$ present); from $L$. sripadensis by having four infralabials ( $v s$ five), paravertebrals 48 ( $v s$ 56-58), ventrals 46-48 ( vs 52-58), two primary temporals ( $v s$ single), last supralabials longitudinally split ( $v s$ entire); and from $L$. taylori by having four infralabials ( $v s$ five), paravertebrals 48 ( $v s 54$ ), ventrals 46-48 (vs 54-56), two primary temporals ( $v s \quad$ single), last supralabials longitudinally split ( $v s$ entire). See Tables 4, 5.

Natural history. A diurnal skink active mostly at $22-27^{\circ} \mathrm{C}$. This is a submontane forest- 
dependent species associated with leaf litter on the forest floor. Most of the individuals were observed in habitats where the leaf-litter thickness is $15-35 \mathrm{~mm}$ with ground temperatures of $21-25{ }^{\circ} \mathrm{C}$. This species prefers shady habitats with high canopy cover of 9095\%. It is sympatric with Lankascincus merrill and $L$. cf. taprobanensis in some localities.

Distribution. This species is restricted to the higher elevations $(1,000 \mathrm{~m}$ a.s.l.) of the submontane forests in the Rakwana Hills (Morningside) in southwestern Sri Lanka. See the map (Fig. 8) for confirmed locality data based on museum specimens and personal observations.

Lankascincus cf. gansi Greer, 1991

(Figs. 1, 6-8, Tables 1, 3-6)

Lankascincus gansi — Batuwita 2019 [Partim]

Specimens examined $(\boldsymbol{n}=\mathbf{3})$. Adult males, WHT 6780, SVL $36.3 \mathrm{~mm}$, collected from Gannoruwa $\left(07^{\circ} 17^{\prime} \mathrm{N}, 80^{\circ} 35^{\prime} \mathrm{E}\right.$, alt. $500 \mathrm{~m}$ a.s.1.), Kandy District, Central Province, Sri Lanka, NMSL 0186b, SVL $32.0 \mathrm{~mm}$ and WHT 6613, SVL 34.0 $\mathrm{mm}$; collected from Kithulgala $\left(06^{\circ} 59^{\prime}\right.$ N, 80 $24^{\prime}$
E, alt. $220 \mathrm{~m}$ a.s.1.), Kegalle District, Sabara gamuwa Province, Sri Lanka.

Among the lowland populations of true L. gansi, the sub population occurs in the lower-central highlands (200-500 $\mathrm{m}$ a.s.l.) show slightly discrete morphological characters, probably another distinct species, treated here as Lankascincus cf. gansi until resolved by integrated taxonomic approaches.

Lankascincus cf. gansi is distinguished from $L$. gansi and $L$. sameerai $\mathrm{sp}$. nov. by having a shorter tail than SVL (vs longer), upper primary temporal imbricate with secondary temporals ( $v s$ juxtaposed), throat scales rhomboid and juxtaposed ( $v s$ cycloid and imbricate), and a unique colouration of golden yellow venter, bluish black throat with white flecks on labials, lower temporal region until shoulders, but no flecks on throat and neck, scarlet orange neck in breeding males, otherwise golden yellow. However we are not confident enough that these morphological characters are distinct enough to assign a new name, hence it will remain as $L$. cf. gansi, until it can be clarified whether these are sub population variations or distinctive species characters using genetic data.

Table 2. Selected Morphometric (in $\mathrm{mm}$ ) and meristic characters of the holotype and paratypes of Lankascincus sameerai sp. nov. and three topotypes of L. gansi.

\begin{tabular}{|c|c|c|c|c|c|c|c|c|c|}
\hline \multirow{5}{*}{ Character } & \multicolumn{6}{|c|}{ L. sameerai sp. nov. $(n=6)$} & \multirow{2}{*}{\multicolumn{3}{|c|}{$\begin{array}{c}\text { L. gansi }(n=3) \\
\text { topotypes } \\
\end{array}$}} \\
\hline & \multirow{3}{*}{$\begin{array}{c}\text { holotype } \\
\text { male } \\
\text { WHT }\end{array}$} & \multicolumn{5}{|c|}{ paratypes } & & & \\
\hline & & male & male & male & male & female & male & male & female \\
\hline & & WHT & WHT & WHT & WHT & WHT & NMSL & WHT & WHT \\
\hline & 6720 & 1608 & 6741 & $6749 \mathrm{a}$ & $6749 \mathrm{~b}$ & 6593 & 0397-SB & 6664 & 6670 \\
\hline snout-vent length & 36.0 & 36.8 & 35.5 & 35.0 & 35.0 & 35.7 & 30.0 & 34.3 & 32.9 \\
\hline head length & 7.2 & 7.5 & 6.8 & 7.9 & 6.4 & 7.2 & 6.5 & 7.3 & 7.0 \\
\hline head width & 4.2 & 4.6 & 4.8 & 4.5 & 4.3 & 4.3 & 4.3 & 4.0 & 4.3 \\
\hline head depth & 3.2 & 3.5 & 3.2 & 3.2 & 3.1 & 2.8 & 3.1 & 3.3 & 3.3 \\
\hline brachium length & 2.9 & 3.1 & 3.2 & 3.0 & 2.9 & 3.3 & 2.7 & 2.0 & 2.9 \\
\hline antebrachium length & 3.1 & 3.1 & 3.4 & 2.7 & 2.4 & 2.5 & 2.4 & 2.8 & 2.5 \\
\hline palm length & 1.7 & 1.7 & 1.7 & 1.9 & 1.8 & 2.9 & 1.6 & 1.5 & 1.5 \\
\hline thigh length & 4.2 & 4.5 & 4.3 & 3.9 & 3.8 & 4.0 & 3.9 & 4.3 & 4.2 \\
\hline shank length & 5.7 & 5.7 & 5.2 & 4.6 & 4.6 & 5.1 & 5.1 & 4.8 & 5.0 \\
\hline foot length & 4.1 & 4.5 & 3.7 & 3.3 & 3.5 & 3.5 & 2.9 & 3.3 & 3.2 \\
\hline body width & 5.3 & 5.1 & 5.0 & 5.0 & 5.3 & 6.3 & 5.1 & 5.1 & 5.3 \\
\hline body depth & 4.9 & 4.9 & 4.0 & 5.1 & 5.0 & 5.6 & 4.5 & 4.0 & 3.9 \\
\hline axilla-groin length & 17.9 & 18.2 & 17.2 & 20.0 & 20.0 & 21.0 & 15.6 & 17.0 & 17.3 \\
\hline tail base width & 3.6 & 4.0 & 3.3 & 3.7 & 3.5 & 4.2 & 3.5 & 3.3 & 4.1 \\
\hline tail length & 43.0 & 40.0 & 46.5 & 47.7 & 39.4 & 53.3 & 36.0 & 40.9 & 23.2 \\
\hline supralabials & 7 & 7 & 7 & 7 & 7 & 7 & 7 & 7 & 7 \\
\hline infralabials & 4 & 4 & 4 & 4 & 4 & 4 & 5 & 5 & 5 \\
\hline paravertebrals & 48 & 48 & 48 & 48 & 48 & 48 & 46 & 46 & 48 \\
\hline midbody scale rows & 26 & 26 & 26 & 26 & 26 & 26 & 24 & 24 & 24 \\
\hline ventrals & 48 & 48 & 48 & 48 & 46 & 48 & 46 & 48 & 46 \\
\hline lamellae finger IV & 8 & 7 & 8 & 8 & 8 & 8 & 9 & 9 & 9 \\
\hline lamellae toe IV & 13 & 12 & 12 & 12 & 13 & 12 & 14 & 13 & 13 \\
\hline
\end{tabular}




\section{Plate 41}

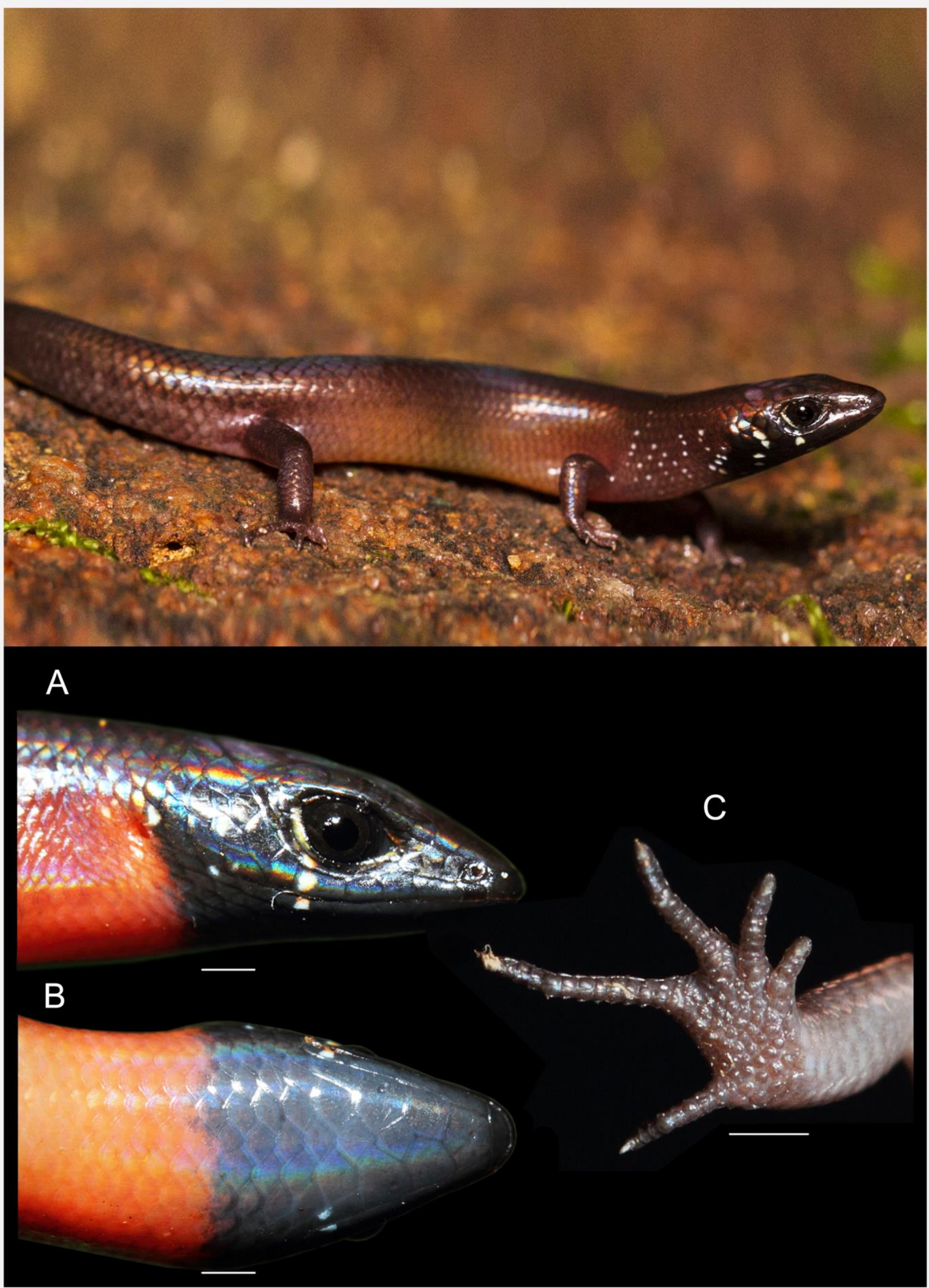

Figure 6. Lankascincus cf. gansi, a breeding male (not collected) from Kithulgala in low-elevations of the central highlands of Sri Lanka (SVL $34.0 \mathrm{~mm}$ ); head in (A) lateral view, (B) ventral view, and (C) ventral side of the foot (scale: $1 \mathrm{~mm}$ ). 


\section{Plate 42}

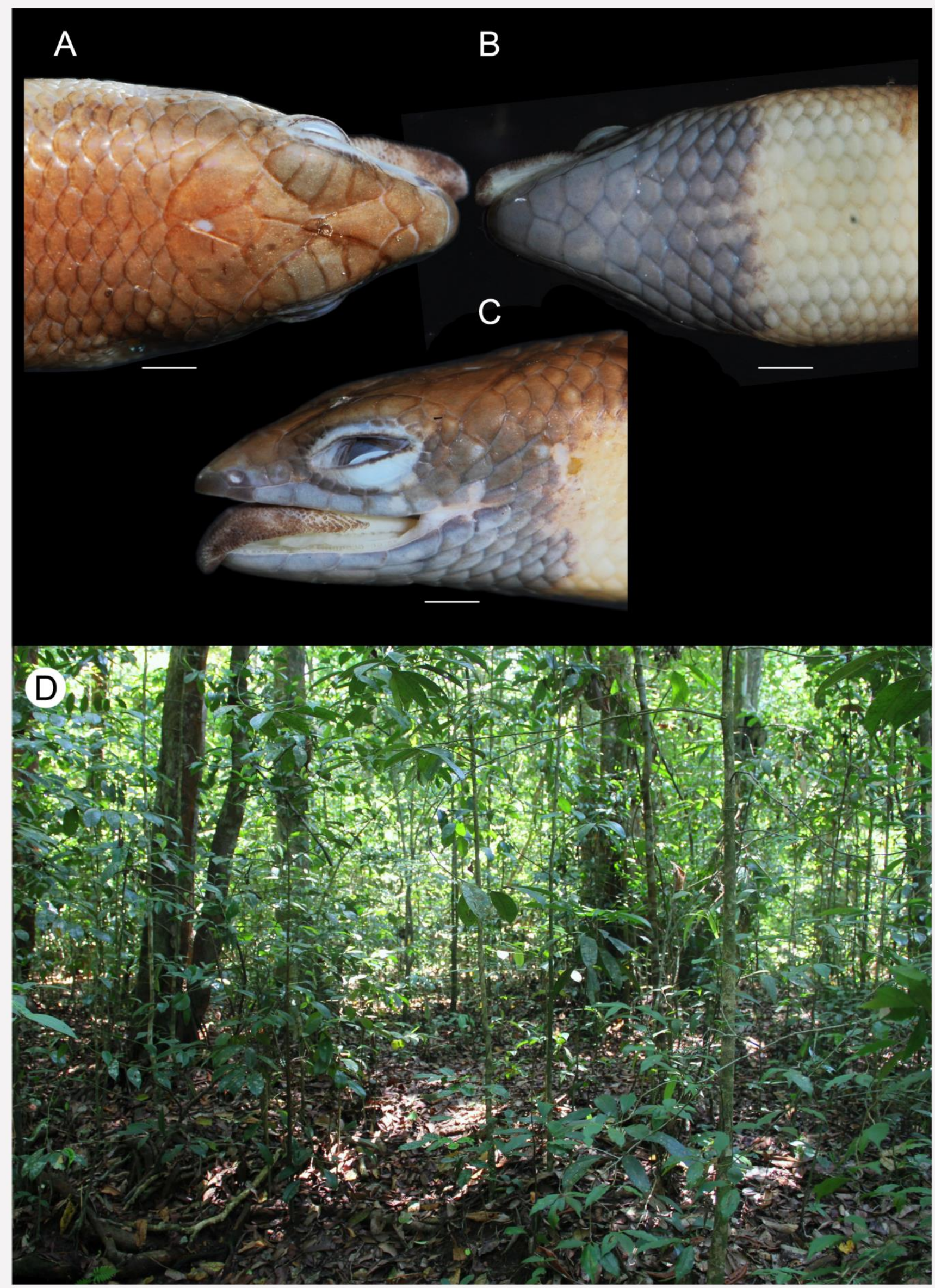

Figure 7. Lankascincus cf. gansi, adult male (NMSL uncat. WHT 6780) from Gannoruwa (SVL $36.3 \mathrm{~mm}$ ), head in (A) dorsal view, (B) ventral view, (C) lateral view (scale: $1 \mathrm{~mm}$ ); and (D) the habitat: lowland forests in the western slopes of the central highlands. Photo (C) D.M.S. Suranjan Karunarathna. 
Table 3. Selected diagnostic morphometric (in mm), meristric, and morphological characters of the species of the Lankascincus gansi complex and L. merrill including data of onomatophores; " - " = not measured

\begin{tabular}{|c|c|c|c|c|c|c|c|}
\hline \multirow[b]{2}{*}{ Character } & \multirow{2}{*}{$\begin{array}{c}\text { L. cf. gansi } \\
\text { males } \\
(n=3)\end{array}$} & \multicolumn{2}{|c|}{ L. sameerai sp. nov. } & \multicolumn{2}{|c|}{ L. gansi } & \multicolumn{2}{|c|}{ L. merrill } \\
\hline & & $\begin{array}{l}\text { males } \\
(n=5)\end{array}$ & $\begin{array}{c}\text { female } \\
(n=1)\end{array}$ & $\begin{array}{l}\text { males } \\
(n=7)\end{array}$ & $\begin{array}{c}\text { females } \\
(n=4)\end{array}$ & $\begin{array}{l}\text { males } \\
(n=3)\end{array}$ & $\begin{array}{c}\text { females } \\
(n=2)\end{array}$ \\
\hline snout-vent length & $32.0-36.3$ & $35.0-36.8$ & 35.7 & $30.0-34.3$ & $30.5-32.9$ & $32.8-34.9$ & $33.7-34.0$ \\
\hline relative (TL/SVL) & $0.80-0.94$ & $1.09-1.36$ & 1.49 & $1.01-1.32$ & $1.01-1.18$ & $1.28-1.56$ & $1.35-1.48$ \\
\hline head length (HL) & $7.1-7.3$ & $6.4-7.9$ & 7.2 & $6.4-7.3$ & $6.3-7.0$ & $6.4-8.3$ & $7.2-7.4$ \\
\hline head width (HW) & $4.6-4.8$ & $4.2-4.8$ & 4.3 & $3.9-4.4$ & $4.1-4.3$ & $4.0-4.9$ & $4.5-4.7$ \\
\hline brachium length (UAL) & $2.7-3.4$ & $2.9-3.2$ & 3.3 & $2.0-3.1$ & $2.7-2.9$ & - & - \\
\hline antebrachium length (LAL) & $2.6-3.1$ & $2.4-3.4$ & 2.5 & $2.3-2.8$ & $2.2-2.7$ & - & - \\
\hline thigh length & $4.1-4.4$ & $3.8-4.5$ & 4.0 & $3.5-4.3$ & $3.5-4.2$ & - & - \\
\hline shank length & $5.2-5.9$ & $4.6-5.7$ & 5.1 & $4.7-5.1$ & $4.5-5.0$ & - & - \\
\hline foot length (FOL) & $4.2-4.5$ & $3.3-4.5$ & 3.5 & $2.9-3.7$ & $2.9-3.4$ & - & - \\
\hline axilla-groin length & $13.9-16.8$ & $17.2-20.0$ & 21.0 & $14.5-17.9$ & $16.8-17.3$ & $17.2-19.3$ & $18.4-18.8$ \\
\hline tail length & $28.9-30.0$ & $39.4-47.7$ & 53.3 & $32.5-42.7$ & $31.5-36.0$ & $43.0-51.2$ & $45.9-49.9$ \\
\hline suboculars & 9 & 9 & 9 & 9 & 9 & 10 & 10 \\
\hline infralabials & 5 & 4 & 4 & 5 & 5 & 5 & 5 \\
\hline paravertebrals & $48-50$ & 48 & 48 & 46 & $46-48$ & $47-48$ & 48 \\
\hline midbody scale rows & $23-24$ & 26 & 26 & 24 & 24 & $24-26$ & 24 \\
\hline ventrals & $46-48$ & $46-48$ & 48 & $46-48$ & $46-48$ & $49-52$ & $50-51$ \\
\hline lamellae on finger IV & 9 & $7-8$ & 8 & 8 & 8 & 9 & $8-10$ \\
\hline lamellae on toe IV & 13 & $12-13$ & 12 & $13-15$ & $12-13$ & $14-16$ & $13-14$ \\
\hline $\begin{array}{l}\text { upper primary temporal imbricate (1), juxtaposed (0) with } \\
\text { secondary temporal }\end{array}$ & 1 & & & & & & \\
\hline $\begin{array}{l}\text { upper secondary temporal imbricate }(1) \text {, juxtaposed }(0) \\
\text { with lower secondary temporal }\end{array}$ & 1 & & & & & & \\
\hline $\begin{array}{l}\text { frontal shorter }(1) \text {, equal }(0) \text { in frontoparietal }+ \\
\text { interparietal length combined }\end{array}$ & 0 & & & & & & \\
\hline throat scales cycloid $(0)$, rhomboid $(1)$ & 1 & & & & & & \\
\hline throat scales juxtaposed $(0)$, imbricate $(1)$ & 0 & & & & & & \\
\hline throat colour & bluish black & dark gr & black & dark gr & h brown & & own \\
\hline neck colour & scarlet orange & dark & & & & & own \\
\hline flecks on throat and neck absent (0), present (1) & 0 & & & & & & \\
\hline flecks on lateral head yellow (1), white ( 0$)$ colour & 0 & & & & & & \\
\hline dorso-lateral longitudinal stripe absent $(0)$, present (1) & 0 & & & & & & \\
\hline
\end{tabular}


Table 4. Selected morphometric and meristic characters of the Lankascincus species; “-” = not evaluated.

\begin{tabular}{|c|c|c|c|c|c|c|c|c|c|c|c|}
\hline \multirow[b]{2}{*}{ Character } & \multicolumn{2}{|c|}{ dorsicatenatus group } & \multirow[b]{2}{*}{ 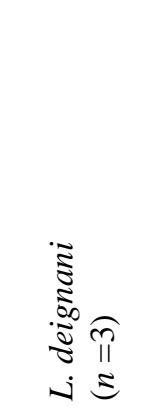 } & \multirow[b]{2}{*}{ 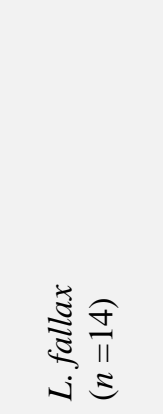 } & \multicolumn{3}{|c|}{ gansi group } & \multirow[b]{2}{*}{ 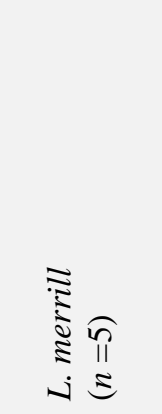 } & \multirow[b]{2}{*}{ 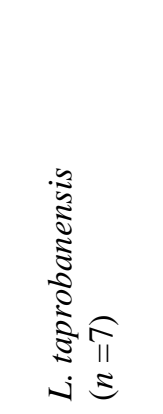 } & \multicolumn{2}{|c|}{ taylori group } \\
\hline & 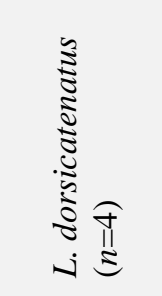 & 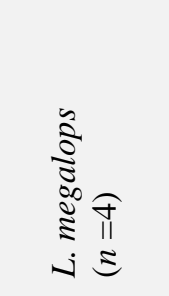 & & & 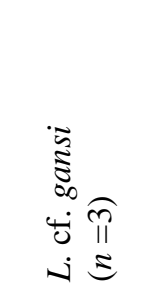 & 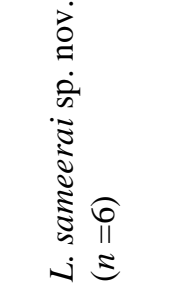 & 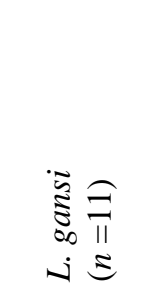 & & & 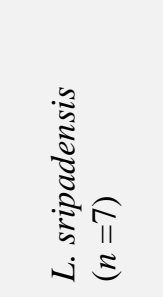 & 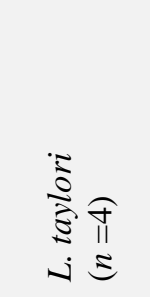 \\
\hline snout-vent length & $30.3-40.5$ & $38.0-44.5$ & $52.6-60.2$ & $33.2-44.5$ & $32.0-36.3$ & $35.0-36.8$ & $30.0-34.3$ & $32.8-34.9$ & $40.0-45.8$ & $41.1-58.2$ & $37.5-41.4$ \\
\hline head length & $7.3-8.9$ & $8.5-10.1$ & $12.0-13.4$ & $6.7-8.8$ & $7.1-7.3$ & $6.4-7.9$ & $6.3-7.3$ & $6.4-8.3$ & $7.1-9.7$ & $7.6-11.9$ & $7.2-8.9$ \\
\hline head width & $4.9-6.0$ & $5.3-6.2$ & $6.3-7.1$ & $4.1-6.4$ & $4.6-4.8$ & $4.2-4.8$ & $3.9-4.4$ & $4.0-4.9$ & $3.6-5.2$ & $5.1-7.9$ & $4.3-5.3$ \\
\hline head depth & $3.2-4.8$ & $4.3-4.6$ & $8.1-9.0$ & $2.9-5.4$ & $3.1-3.2$ & $2.8-3.5$ & $2.0-3.3$ & $3.0-3.6$ & $4.9-6.7$ & $4.2-6.1$ & $5.2-6.8$ \\
\hline brachium length & $2.4-3.7$ & $3.3-4.7$ & $5.8-5.9$ & $2.4-3.6$ & $2.7-3.4$ & $2.9-3.3$ & $2.3-3.1$ & - & $2.8-3.2$ & $3.2-5.2$ & $2.9-3.7$ \\
\hline antebrachium length & $3.0-3.7$ & $3.6-4.2$ & $5.1-5.6$ & $1.8-3.8$ & $2.6-3.1$ & $2.4-3.4$ & $2.2-2.8$ & $2.5-2.7$ & $2.8-3.6$ & $2.7-4.5$ & $2.9-3.2$ \\
\hline palm length & $2.5-3.2$ & $2.0-3.3$ & $4.0-4.5$ & $1.3-2.4$ & $1.7-2.0$ & $1.7-2.9$ & $1.4-1.9$ & - & $1.9-2.3$ & $2.0-3.9$ & $1.5-2.3$ \\
\hline thigh length & $4.2-5.0$ & $4.9-6.3$ & $7.5-7.8$ & $3.8-6.4$ & $4.1-4.4$ & $3.8-4.5$ & $3.5-4.3$ & - & $3.8-4.9$ & $4.5-6.9$ & $3.4-4.4$ \\
\hline shank length & $6.0-7.3$ & $7.5-8.3$ & $11.5-11.9$ & $4.7-9.7$ & $5.2-5.9$ & $4.6-5.7$ & $4.5-5.1$ & $3.7-3.8$ & $4.4-6.3$ & $5.6-9.2$ & $3.0-5.4$ \\
\hline foot length & $5.3-6.6$ & $6.4-8.0$ & $8.5-9.8$ & $3.8-4.9$ & $4.2-4.5$ & $3.3-4.5$ & $2.9-3.7$ & - & $3.8-8.5$ & $4.4-8.6$ & $3.9-5.8$ \\
\hline body width & $4.9-7.5$ & $6.1-8.3$ & $6.4-7.3$ & $4.3-8.3$ & $5.2-5.9$ & $5.0-6.3$ & $4.1-5.3$ & - & $3.4-6.9$ & $6.0-8.9$ & $5.9-6.7$ \\
\hline body depth & $4.3-5.8$ & $5.2-7.5$ & $9.0-11.8$ & $3.5-6.9$ & $4.5-4.7$ & $4.0-5.6$ & $3.9-4.6$ & - & $5.3-7.2$ & $5.7-7.6$ & $6.0-6.5$ \\
\hline axilla-groin length & $14.9-20.2$ & $20.0-23.9$ & $24.1-29.0$ & $17.5-24.1$ & $13.9-16.8$ & $17.2-21$ & $14.5-17.9$ & $17.2-19.3$ & $20.7-25.6$ & $22.7-30.7$ & $15.9-24.2$ \\
\hline tail base width & $3.2-4.5$ & $3.7-4.5$ & $6.2-6.6$ & $3.5-5.3$ & $3.5-4.0$ & $3.3-4.2$ & $2.5-3.7$ & $3.3-4.1$ & $3.1-5.4$ & $3.0-5.6$ & $4.1-5.6$ \\
\hline tail length & $46.0-57.4$ & $56.0-74.0$ & $54.5-80.0$ & $32.5-72.5$ & $28.9-30.0$ & $39.4-53.3$ & $29.8-42.7$ & $45.9-51.2$ & $39.5-62.2$ & $55.6-86.0$ & $25.7-56.7$ \\
\hline supralabials & 7 & 7 & 7 & 7 & 7 & 7 & 7 & 7 & 6 & 7 & 7 \\
\hline supralabial at mid orbit & 5 & 5 & 5 & 5 & 5 & 5 & 5 & 5 & 4 & 5 & 5 \\
\hline suboculars & 9 & 9 & 9 & 8 or 9 & 9 & 9 & 9 & 10 & 7 & 8 & 7 \\
\hline supraciliaries & 10 & 10 & 10 & 8 & 9 & 9 & 9 & 9 & 8 & 8 & 8 \\
\hline infralabials & 5 & 5 & 5 & 5 & 5 & 4 & 5 & 5 & 6 & 5 & 5 \\
\hline paravertebrals & $46-48$ & 47 or 48 & $46-48$ & $48-53$ & $48-50$ & 48 & $46-48$ & 47 or 48 & $58-63$ & $56-58$ & 54 \\
\hline midbody scale rows & 26 & 26 & 28 & $24-28$ & 23 or 24 & 26 & 24 & $24-26$ & $26-28$ & 26 & 26 or 27 \\
\hline ventrals & $48-50$ & $48-50$ & $48-57$ & $49-58$ & $46-48$ & $46-48$ & $46-48$ & $49-52$ & $59-64$ & $52-58$ & $54-56$ \\
\hline lamellae on finger IV & $9-12$ & 10 or 11 & $11-14$ & $8-11$ & 9 & 7 or 8 & 8 & $8-10$ & $8-10$ & $10-13$ & 8 or 9 \\
\hline lamellae on toe IV & $16-18$ & 17 or 18 & $19-20$ & $12-17$ & 13 & 12 or 13 & $12-15$ & $13-16$ & $10-15$ & $14-19$ & $12-15$ \\
\hline
\end{tabular}


Table 5. Selected diagnostic characters of the Lankascincus species; "_-" = not evaluated.

\begin{tabular}{|c|c|c|c|c|c|c|c|c|c|c|c|}
\hline Character & 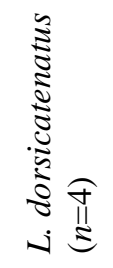 & 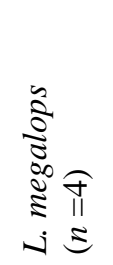 & 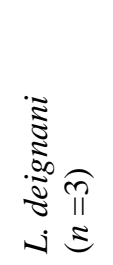 & 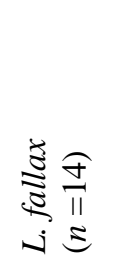 & 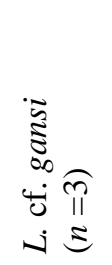 & 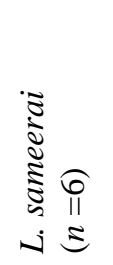 & 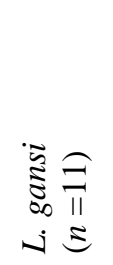 & 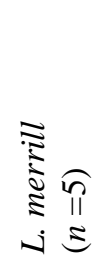 & 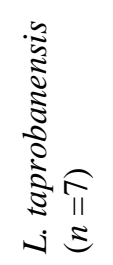 & 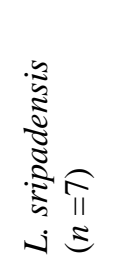 & 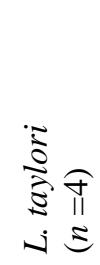 \\
\hline maximum SVL & 40.5 & 44.5 & 60.2 & 44.5 & 36.3 & 36.8 & 34.3 & 34.9 & 49.5 & 58.2 & 41.4 \\
\hline tail (TL) shorter (0), longer (1) than SVL & 1 & 1 & 1 & 1 & 0 & 1 & 1 & 1 & 1 & 1 & 1 \\
\hline supralabials & 7 & 7 & 7 & 7 & 7 & 7 & 7 & 7 & 6 & 7 & 7 \\
\hline supralabial at mid orbit & 5 & 5 & 5 & 5 & 5 & 5 & 5 & 5 & 4 & 5 & 5 \\
\hline suboculars & 9 & 9 & 9 & 8,9 & 9 & 9 & 9 & 10 & 7 & 8 & 7 \\
\hline infralabials & 5 & 5 & 5 & 5 & 5 & 4 & 5 & 5 & 6 & 5 & 5 \\
\hline loreal & 2 & 2 & 2 & 2 & 2 & 2 & 2 & 2 & 1,2 & 2 & 2 \\
\hline paravertebrals & $46-48$ & 47,48 & $46-48$ & $48-53$ & $48-50$ & 48 & $46-48$ & 47,48 & $53-63$ & $56-58$ & 54 \\
\hline midbody scale rows & 26 & 26 & 28 & $24-28$ & 23,24 & 26 & 24 & $24-26$ & $26-28$ & 26 & 26,27 \\
\hline ventrals & $48-50$ & $48-50$ & $48-57$ & $49-58$ & $46-48$ & $46-48$ & $46-48$ & $49-52$ & $59-64$ & $52-58$ & $54-56$ \\
\hline lamellae on finger IV & $9-12$ & 10,11 & $11-14$ & $8-11$ & 9 & 7,8 & 8 & $8-10$ & $8-10$ & $10-13$ & 8,9 \\
\hline lamellae on toe IV & $16-18$ & 17,18 & $19-20$ & $12-17$ & 13 & 12,13 & $12-15$ & $13-16$ & $10-15$ & $14-19$ & $12-15$ \\
\hline number of primary temporals & 2 & 2 & 1 & 2 & 2 & 2 & 2 & 2 & 1 & 1 & 1 \\
\hline prefrontals separated $(0) /$ in contact narrow/broad (1) & 1 & 1 & 1 & 1 & 1 & 1 & 1 & 1 & 0 & 1 & 1 \\
\hline frontoparietals fused $(0) /$ paired $(1)$ & 1 & 1 & 1 & 0,1 & 1 & 1 & 1 & 1 & 1 & 1 & 1 \\
\hline $\begin{array}{l}\text { frontal shorter (1)/ equal (0) in frontoparietal + interparietal length } \\
\text { combined }\end{array}$ & 0 & 0 & 0 & 1 & 0 & 0 & 1 & 1 & 0 & 0 & 1 \\
\hline $2^{\text {nd }}$ supraocular widest in transverse $(0) /$ longitudinal (1) & 1 & 1 & 1 & 1 & 0 & 0 & 0 & 1 & 1 & 0 & 0 \\
\hline last supralabial longitudinally split (1)/ not split (0) & 1 & 1 & 0 & 0 & 1 & 1 & 1 & 1 & 0 & 0 & 0 \\
\hline $\begin{array}{l}\text { primary temporal juxtaposed }(0) / \text { imbricate }(1) \text { with lower secondary } \\
\text { temporal }\end{array}$ & 0 & 0 & 1 & 0 & 1 & 0 & 0 & 0 & 0 & 0 & 0 \\
\hline throat scales cycloid $(0) /$ rhomboid $(1)$ & 0 & 0 & 0 & 0 & 1 & 0 & 0 & 1 & 0 & 0 & 0 \\
\hline throat scales imbricate $(1) /$ juxtaposed $(0)$ & 1 & 1 & 1 & 1 & 0 & 1 & 1 & 1 & 1 & 1 & 1 \\
\hline white blotch beneath eye absent $(0)$, present (1) & 0 & 0 & 1 & 0 & 0 & 0 & 0 & 0 & 0 & 0 & 0 \\
\hline dark dorso-lateral longitudinal stripe absent $(0)$, present (1) & 1 & 1 & 0 & 0 & 0 & 0 & 0 & 1 & 1 & 0 & 0 \\
\hline $\begin{array}{l}\text { Throat colour of breeding males: pale [brown/pink/yellow/cream] (0)/ } \\
\text { bright [red/scarlet/golden] (1)/ dark [black/gray/blue] (2) }\end{array}$ & $0,1,2$ & $0,1,2$ & 0 & 1,2 & 2 & 2 & 0 & 0 & 2 & 0 & 2 \\
\hline neck colour of breeding males: pale (0), bright $(1)$, dark (2) & 1 & 1 & 0 & 1 & 1 & 0 & 2 & 0 & 1 & 0 & 2 \\
\hline flecks or blotches on throat and neck absent (0), present (1) & 0 & 0 & 1 & 1 & 0 & 0 & 1 & 1 & 0 & 1 & 1 \\
\hline
\end{tabular}




\section{Discussion}

When the genus Lankascincus was erected, Greer (1991) described three new species and provided re-descriptions of three new combinations for the genus. However, all of these six descriptions are very brief and lack most of the diagnostic morphological, morphometric, and meristic characters. Subsequent authors have not made any attempt to provide comprehensive re-descriptions until Batuwita (2019) compiled a review of the genus.

Although it is claimed as a review of Lankascincus, Batuwita (2019) did not provide any individual morphometric or meristic data for either onomatophore nor topotypes, and all the re-descriptions are based on vouchers deposited at local museums, collected from many biogeographic regions within Sri Lanka (which share many unnamed species). Further, morphometric characters are provided as ranges, thus it is not clear whether the name-bearing type specimens are included within those ranges or not, because in most of the cases, the number of specimens in the examined material and tables are not in accordance. For example, Batuwita (2019) examined 20 specimens of $L$. gansi including the holotype (CM 67932), but in table 3, provided morphometric and meristic characters for only 19 specimens as a range. In that case it seems that, although Batuwita (2019) claimed that he examined the holotype, he was unable to provide data of that specimen, and the same is likely the case for other species in this review.

Furthermore, table 2 of Batuwita (2019) presented L. megalops (a new combination) in comparison with dorsicatenatus which are truly close species. However, we were unable to identify any diagnosable characters between this new combination and $L$. dorsicatenatus, except for 47-50 paravertebrals (vs. 40-46). Based on the topotype specimens (both live and preserved) we never observed such a distinct paravertebral count range. A re-evaluation on the new combination of L. megalops is essential to stabilise the nomenclatural issues of the genus.

In the re-description of Lankascincus gansi, there is no specific specimen used for the particular species description, which as defined by Batuwita (2019) contains all two distinct morphospecies ( $L$. gansi and L. sameerai sp. nov.) and a distinct subpopulation, $L$. cf. gansi identified here. Batuwita (2019) considered $L$. gansi (sensu lato) distributed in the south- western wet zone and the Central highlands from sea level to $1,100 \mathrm{~m}$ a.s.l., although some isolated populations are clearly visible in his figure 4. Although Batuwita (2019) noted the peculiarity of finding Lankascincus gansi from high altitudes in the Rakwana Hills (Morningside), he had not hitherto compared them with the lowland rainforest population from which L. gansi was originally described. Our results support distinguishing that population as a distinct species based on morphological and morphometric characters, hence the assigned a new name. Our current understanding of patterns of biogeographic isolation in this area of Sri Lanka further supports recognizing this form as a distinct species. Currently we are re-assessing the morphology of the genus Lankascincus (work in progress), parallel to the study on population genetics and phylogeography carried out by $\mathrm{K}$. Ukuwela and party (work in progress).

Based on previous studies it has been clearly understood that lowland rainforests and upper Rakwana Hills (alt. 1,000 m a.s.1.) are different biogeographic regions. However the lower central highlands (alt. 200-500 m a.s.1.) has not yet been recognised as a distinct biogeographic zone, although this has been suggested by previous studies on the genera Pseudophilautus (shrub frogs), Rhinophis (tail-shield snakes), and Cnemaspis (day geckos). In these groups most of the wet zone species complexes are divided into distinct species in the lowland rainforests (alt. 0-300 $\mathrm{m}$ a.s.1.), lower-central highlands, and upper Rakwana Hills. Among the genus Pseudophilautus, P. mittermeieri is restricted to the south-western lowland wet zone, and its congener, $P$. decoris is restricted to the upper Rakwana Hills (Manamendra-Arachchi \& Pethiyagoda 2005, Meegaskumbura \& Manamendra-Arachchi 2005). Similarly in the genus Cnemaspis, C. silvula is restricted to the south-western lowland wet zone, and its congeners, C. pava and C. pulchra are restricted to the lower-central highlands and upper Rakwana Hills respectively. In the genus Rhinophis, R. blythii is restricted to the midcentral highlands and its congener, $R$. erangaviraji is restricted to upper Rakwana Hills (Wickramasinghe et al. 2009, Pyron et al. 2016, de Silva \& Ukuwela 2017). Similarly in this study, Lankascincus gansi is restricted to the lowland wet zone, and its congeners, $L$. cf. gansi and $L$. sameerai sp. nov. are restricted to the lower-central highlands and upper Rakwana 
Hills respectively.

In addition to such factors as the climate, elevation, vegetation, soil type etc., the river basin network may act as a potential barrier to the dispersal for some tiny litter-dwelling species like $L$. gansi. We assume for the dispersal between the lower-central highland population, $L$. cf. gansi and the lowland rainforest population, L. gansi, the Kelani and Kalu Rivers act as a potential barrier (Fig. 8). Following the biogeographic regions suggested by Amarasinghe \& Karunarathna (2020), we modify the current biogeographic zonation for the genus Lankascincus (Table 6), based on morphological relationships. Further research on phylogenetic relationships may slightly modify the representation of current distribution patterns, and may further clarify their distributions.

Therefore, as suggested by Batuwita (2019), the relationships of these populations need to be resolved by integrated taxonomic approaches (currently work in progress by us and $\mathrm{K}$. Ukuwela and party).

Table 6. Current distribution patterns of the Lankascincus species in each biogeographic region; modified after Amarasinghe \& Karunarathna 2020; “_”” not recorded yet. [L. fallax occur in every region below $300 \mathrm{~m}$ a.s.1.]

\begin{tabular}{|c|c|c|c|}
\hline \multirow{2}{*}{ Biogeographic region (alt. range a.s.1.) } & \multicolumn{3}{|c|}{ Lankascincus groups } \\
\hline & gansi group & taylori group & Other \\
\hline \multicolumn{4}{|l|}{ (1). Wet Zone } \\
\hline Lowland (0-300 m) & L. gansi & - & $\begin{array}{l}\text { L. dorsicatenatus } \\
\text { L. deignani }\end{array}$ \\
\hline Rakwana Hills (above $400 \mathrm{~m}$ ) & - & L. taylori & - \\
\hline Central highland rainforests $(200-700 \mathrm{~m})$ & L. cf. gansi & L. taylori & $\begin{array}{l}\text { L. megalops } \\
\text { L. deignani }\end{array}$ \\
\hline Central highland submontane $(500-900 \mathrm{~m})$ & - & L. taylori & - \\
\hline Central highlands montane $(900-1,500 \mathrm{~m})$ & - & L. sripadensis & $\begin{array}{l}\text { L. taprobanensis } \\
\text { (L. munindradasi) }\end{array}$ \\
\hline Central highlands montane (above $1,500 \mathrm{~m}$ ) & - & - & L. taprobanensis \\
\hline \multicolumn{4}{|l|}{ (2). Intermediate Zone } \\
\hline Lowland isolated hills $(400-600 \mathrm{~m})$ & - & L. taylori & - \\
\hline Rakwana Hills (above 900 m) & L. sameerai & & L. merrill \\
\hline Knuckles submontane (300-700 m) & - & - & - \\
\hline Knuckles montane (above $700 \mathrm{~m}$ ) & - & L. taylori & - \\
\hline \multicolumn{4}{|l|}{ (3). Dry Zone } \\
\hline Lowland $(0-300 \mathrm{~m})$ & - & - & - \\
\hline
\end{tabular}

In the original description of Lankascincus greeri, Batuwita \& Pethiyagoda (2007: 84) stated that " $L$. greeri is distinguished from $L$. deignani in having 42-45 paravertebrals (vs 51$55) .$. ", further in their comparative materials, they listed 14 specimens of L. deignani collected from different localities, although these specimens were identified erroneously (see Table 7). Also they had not examined the holotype of L. deignani (USNM 120326) collected from Gannoruwa, Kandy (alt. 500 m a.s.l.). It is clear, therefore, that they described $L$. greeri without comparison with $L$. deignani, the closest congener for their new species. After 12 years, Batuwita (2019), without providing any clarification, re-identified 12 specimens (out of 14 listed as L. deignani in Batuwita \& Pethiyagoda 2007; two specimens not listed therein) as L. sripadenssis. Furthermore, they examined two specimens of L. deignani [the holotype (USNM 120326) and WHT 6757 from type locality]. We compared the data of the above two specimens in Batuwita (2019), with the data provided in the original description of $L$. greeri (see Table 8). Based on the comparison (fide Batuwita 2019) it is obvious that there are no morphological diagnostic characters to distinguish these two species, except for "adpressed limbs slightly imbricate" and no suborbital pale spot in L. deignani [vs. opposite in L. greeri (fide Batuwita 2019). We have observed such characters are individual variations, even within one population. The hypothesis of biogegraphic isolation by river basins mentioned above is not always applicable for widespread species distributed continously without any interruption between river basins. In this case, it may not be supported for larger 
bodied skinks, with mean SVL above $50.0 \mathrm{~mm}$ for adults (compared to smaller bodied members in the L. gansi group, mean SVL below 35.0 $\mathrm{mm})$. The species corresponding to $L$. greeri + L. deignani occurs continously from the lowland wet zone until mid-elevations of the Central highlands (vs L. gansi $+L$. cf. gansi distribution is interrupted, with no records in between the Kelani and Kalu River basins). Such a continously widespread single species, in this case $L$. deignani, can be easily distinguished by the wide range of ventrals, usually 10 scales.
However, interupted/isolated widespread multiple species groups have a very narrow range of ventrals, usually 3-4 scales, in this case L. gansi.

Considering the lack of distinctiveness based on morphology as well as biogeography we here synonymise Lankascincus greeri Batuwita \& Pethiyagoda, 2007 with L. deignani (Taylor, 1950). Therefore, in the comparison with the two new species describe here (Tables 4-5), we consider L. deignani as an individual species, not a species group or complex.

Table 7. Lankascincus specimens examined by Batuwita \& Pethiyagoda (2007) and Batuwita (2019)

\begin{tabular}{|c|c|c|c|}
\hline \multirow[b]{2}{*}{ Catalogue No. } & \multirow[b]{2}{*}{ Collected location } & \multicolumn{2}{|c|}{ Identification by } \\
\hline & & $\begin{array}{c}\text { Batuwita \& } \\
\text { Pethiyagoda (2007) }\end{array}$ & $\begin{array}{c}\text { Batuwita } \\
(2019)\end{array}$ \\
\hline USNM 120326 & Mount Ganoruwa (=Gannoruwa, Kandy) & not examined & L. deignani \\
\hline WHT 5416 & & L. deignani & not examined \\
\hline WHT 5417 & & L. deignani & not examined \\
\hline WHT 6566 & Agra Arboretum, Agarapatana & L. deignani & L. sripadensis \\
\hline WHT 6568 & & L. deignani & L. sripadensis \\
\hline WHT 6569 & Garden near Nanu Oya Railway Station & L. deignani & L. sripadensis \\
\hline WHT 6567 & Dimbula-Patana & L. deignani & L. sripadensis \\
\hline WHT $2013 a-f$ & Moray Estate, Rajamallay & L. deignani & L. sripadensis \\
\hline WHT 6739 & Bogawantalawa-Balangoda Road near Udugma & L. deignani & L. sripadensis \\
\hline WHT 6757 & Gannoruwa Forest Reserve, Peradeniya & not examined & L. deignani \\
\hline
\end{tabular}

Table 8. Meristic characters of Lankascincus greeri (fide Batuwita \& Pethiyagoda 2007) and L. deignani (fide Batuwita 2019).

\begin{tabular}{|c|c|c|}
\hline Character & $\begin{array}{c}\text { L. greeri } \\
\text { (fide Batuwita \& Pethiyagoda 2007, Batuwita 2019) }\end{array}$ & $\begin{array}{c}\text { L. deignani } \\
\text { (fide Batuwita 2019) }\end{array}$ \\
\hline midbody scale rows & $26-28$ & 28 \\
\hline ventrals & $55-59$ & 55,57 \\
\hline paravertebrals & $42-45$ & 43,48 \\
\hline supraciliaries & $10-11$ & 9,10 \\
\hline digit IV lamellae: manus & $14-15$ & $9[?], 12$ \\
\hline digit IV lamellae: pes & $19-21$ & 19,20 \\
\hline specimens examined & $\begin{array}{l}\text { holotype: WHT } 6524 \\
\text { paratypes }(n=4): \text { NMSL uncat, WHT } 6525-7\end{array}$ & $\begin{array}{l}\text { holotype: USNM } 120326 \\
\text { topotype: WHT6757 }\end{array}$ \\
\hline
\end{tabular}

An identification key for the Lankascincus species is given below.

1. (a) Seven supralabials, ventrals 58 or less, prefrontals narrowly or broadly in contact ........ 2 (b) Six supralabials, ventrals 59 or more, prefrontals completely separated .

L. taprobanensis

2. (a) Single primary temporal .......................... 3

(b) Two primary temporals

3. (a) Paravertebrals $54-58,2^{\text {nd }}$ supraocular widest in transverse axis, primary temporal juxtaposed with lower secondary temporal, white blotch beneath eye absent ....................................... 4 (b) Paravertebrals 46-48, $2^{\text {nd }}$ supraocular widest in longitudinal axis, primary temporal imbricate with lower secondary temporal, white blotch beneath eye present

L. deignani

4. (a) Maximum SVL $41.4 \mathrm{~mm}$, paravertebrals 54, lamellae on fourth finger 8 or 9 , frontal shorter than interparietal and frontoparietal combined L. taylori (b) Maximum SVL $58.2 \mathrm{~mm}$, paravertebrals 5658 , lamellae on fourth finger 10-13, frontal length subequal with interparietal and frontoparietal combined ............... L. sripadensis 
5. (a) Last supralabial longitudinally split ............. 6 (b) Last supralabial not split ................. L. fallax

6. (a) $2^{\text {nd }}$ supraocular widest in longitudinal axis,

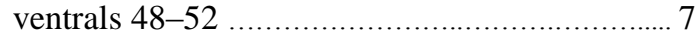
(b) $2^{\text {nd }}$ supraocular widest in transverse axis, ventrals $46-48$..... 9

7. (a) Frontal length subequal with interparietal and frontoparietal combined, throat scales cycloid, lamellae on fourth toe 16-18 .......................... 8 (b) Frontal shorter than interparietal and frontoparietal combined, throat scales rhomboid, lamellae on fourth toe 13-16 . .

L. merrill

8. (a) SVL $40.4 \mathrm{~mm}$

L. dorsicatenatus

(b) SVL $44.5 \mathrm{~mm}$

L. megalops

(Note: no distinct characters to be distinguished)

$8^{\circ}$

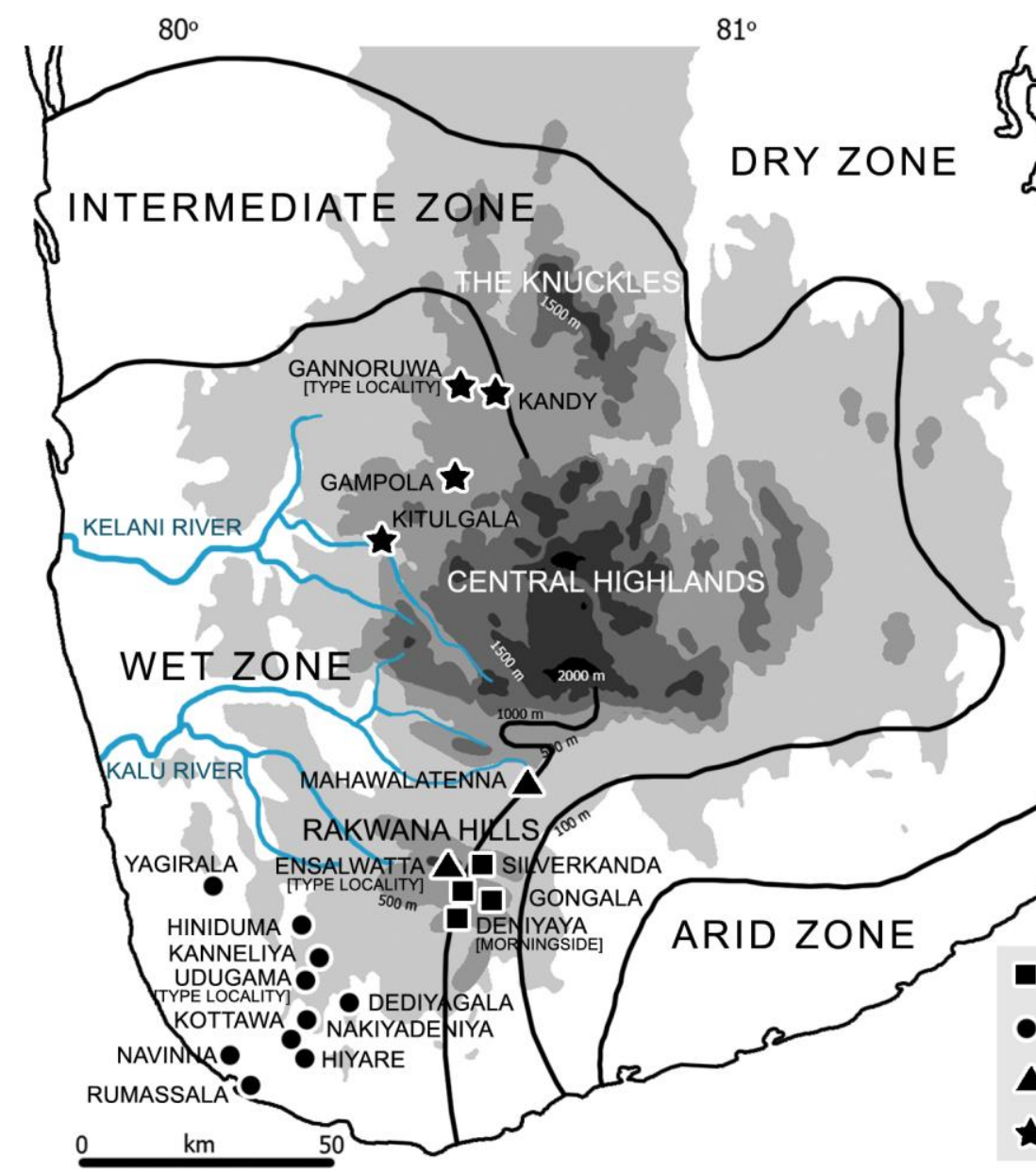

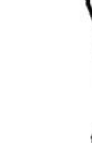

$6^{\circ}$

$81^{\circ}$

9. (a) Tail longer than SVL, primary temporal juxtaposed with lower secondary temporal, throat scales cycloid and imbricate .................. 10 (b) Tail shorter than SVL, primary temporal imbricate with lower secondary temporal, throat scales rhomboid and juxtaposed ........ L. cf. gansi

10. (a) Five infralabials, frontal shorter than interparietal and frontoparietal combined, midbody scale rows 24, dark neck colour in breeding males, white flecks on lateral head, throat and neck ..................................... L. gansi (b) Four infralabials, frontal length subequal with interparietal and frontoparietal combined, midbody scale rows 26 , pale neck colour in breeding males, yellow flecks on lateral head, no flecks on throat and neck ..... L. sameerai sp. nov.

Figure 8. Current distribution map of L. gansi (circles), L. sameerai sp. nov. (squares), L. cf. gansi (stars), and L. merrill (triangles) in Sri Lanka.

\section{Acknowledgements}

We thank the Department of Wildlife Conservation (Permit no. WL/3/2/66/17) and Department of Forest Conservation (R\&E/RES/NFSRCM/2017-04) for granting research permits to SK and DD to carry out field tissue sampling. We thank Aaron Bauer (Villanova University, USA), Kanishka Ukuwela (Rajarata University of Sri Lanka), Philip Bowles (IUCN), and an anonymous 
reviewer for the review of the manuscript and critical comments. Patrick Campbell at BMNH; Nanda Wickramasinghe (former director), Sanuja Kasthuriarachchi (director), Lankani Somaratne, Chamalka Kothalawala, Chandrika Munasinghe, Rasika Dasanayake, Ravindra Wickramanayake, and P. Gunasiri at NMSL are acknowledged for facilitating the in-house study of specimens under their care. Sampath Senaviratne, Himesh Jayasinghe, Suranjan Karunarathna, Hiranya Sudasinghe, Tharindu Ranasinghe, Divanka Randula, Vimukthi Weeratunga, Nadeeka Hapuarachchi, Madura De Silva and Mendis Wickramasinghe for valuable assistance in numerous stages of the study. Also, we wish to thank Dilum Samarasingha and Imesh Jayalath for the support in the field. We also thank Athula Sumathipala (director), Iresha Harischandra, Kaushalaya Jayaweera, Ruwani Cooray, Lakshan Warnakula, Srini Dissanayake, Lakshini Piyasiri at the Institute for research and development, University of Colombo; and J. Supriatna and the staff of the Research Center for Climate Change, University of Indonesia, for their support.

\section{Literature cited}

Amarasinghe, A.A.T. and S. Karunarathna (2020). A new diminutive day gecko species of the genus Cnemaspis Strauch, 1887 (Reptilia: Gekkonidae) from Pilikuttuwa, near the capital of Sri Lanka. Taprobanica, 9 (1): 71-82.

Annandale, A. (1906). New and interesting lizards in Colombo museum. Spolia Zeylanica, 3: 189-192.

Batuwita, S. (2019). A review of the endemic genus Lankascincus (Reptilia : Scincidae: Lygosominae) from Sri Lanka. Bulltin of the Museum of Comparative Zoology, 162 (3): 211-262.

Batuwita, S. and R. Pethiyagoda (2007). Description of a new species of Sri Lankan litter skink (Squamata: Scincidae: Lankascincus). Ceylon Journal of Science (Bio Science), 36 (2): 80-87.

Deraniyagala, P.E.P. (1953). A coloured atlas of some vertebrates from Ceylon: Vol. 2. Tetrapod Reptilia. The Ceylon Government Press: 100 pp.

de Silva, A. and K. Ukuwela (2017). A Naturalist's Guide to the Reptiles of Sri Lanka. John Beaufoy Publishing Ltd., Oxford: 176 pp.

Greer, A. (1991). Lankascincus, a new genus of skink lizards from Sri Lanka, with description of three new species. Journal of Herpetology, 25 (1): 59-64.

ICZN (1999). International Code of Zoological Nomenclature, $4^{\text {th }}$ edition. International Trust for Zoological Nomenclature, London: 306 pp.

Karunarathna, S., N.A. Poyarkov, A. de Silva, M. Madawala, M. Botejue et al. (2019). Integrative taxonomy reveals six new species of day geckos of the genus Cnemaspis Strauch, 1887 (Reptilia: Squamata: Gekkonidae) from geographically isolated hill forests in Sri Lanka. Vertebrate Zoology, 69 (3): 247-298.

Kelaart, E.F. (1854). Descriptions of new Ceylon reptiles. The Annals and magazine of natural history, (2) 13: 407-408.

Manamendra-Arachchi, K. and R. Pethiyagoda (2005). The Sri Lankan shrub frogs of the genus Philautus Gistel, 1848 (Ranidae: Rhacophorinae), with description of 27 new species. In: Yeo, C.J., P.K.L. Ng \& R. Pethiyagoda (Eds.), Contributions to biodiversity exploration and research in Sri Lanka. The Raffles Bulletin of Zoology, Supp. 12: 163-303.

Meegaskumbura, M. and K. ManamendraArachchi (2005). Description of eight new species of shrub frogs (Ranidae: Rhacophorinae: Philautus) from Sri Lanka. In: Yeo, C.J., P.K.L. Ng \& R. Pethiyagoda (Eds.), Contributions to biodiversity exploration and research in Sri Lanka. Raffles Bulletin of Zoology, 12: 305-338.

Peters, W.C.H. (1860). Über einige interessante Amphibien, welche von dem durch seine zoologischen Schriften rühmlichst bekannten österreichischen Naturforscher Professor Schmarda während seiner auf mehrere Welttheile ausgedehnten, besonders auf wirbellose Thiere gerichtet. Monatsberichte der Königlichen Akademie der Wissenschaften, Berlin (April): 182-186.

Pyron R.A., S.R. Ganesh, A. Sayyed, V. Sharma, V. Wallach et al. (2016). A catalogue and systematic overview of the shield-tailed snakes (Serpentes: Uropeltidae). Zoosystema, 38 (4): 453-506.

Somaweera, R. and N. Somaweera (2009). Lizards of Sri Lanka: A Colour Guide with Field Keys. Chimaira, Frankfurt: 304 pp.

Taylor, E.H. (1950). Ceylon lizards of the family Scincidae. University of Kansas Science Bulletin, 33 (2): 481-518.

Wickramassinghe, L.J M., R. Rodrigo, N. Dayawansa, and U. L. D. Jayantha (2007). Two new species of Lankascincus (Squamata: Scincidae) from Sripada Sanctury (Peak 
Wilderness), in Sri Lanka. Zootaxa, 1612 (1): $1-24$.

Wickramasinghe, L.J.M., D.R. Vidanapathirana, N. Wickramasinghe, and P.N. Ranwella (2009). A new species of Rhinophis Hemprich, 1820 (Reptilia: Serpentes: Uropeltidae) from Rakwana massif, Sri Lanka. Zootaxa, 2044: 122.
Wickramasinghe, L.J M., D.R. Vidanapathirana, and N. Wickramasinghe (2020). A new species of Lankascincus Greer, 1991 (Reptilia: Scincidae) from the Rakwana hills of Sri Lanka. Taprobanica, 9 (1): 23-30.

Appendix I. Other specimens examined

Lankascincus gansi (11 ex.): Sri Lanka: Udugama (type locality): NMSL 0397-SB; Kanneliya near Udugama: WHT 6670; Dediyagala near Udugama: WHT 6664; Haycock-Hiniduma: WHT 0151; Kombala-Kottawa Forest Reserve (Hiyare): WHT 6661, 6676; Kottawa: WHT 6672; Nawinna: WHT 6776; Rumassala: WHT 6576, NMSL 0154; Yagirala: WHT 6752.

L. taylori (4 ex.): Sri Lanka: Pundaluoya: BMNH 1872.3.23.4A (holotype), 1872.3.23.4b-c (paratypes), WHT 6707.

L. sripadensis (7 ex.): Sri Lanka: Sripada Sanctuary (Adam's peak): NMSL 2007.05.01 (holotype), 2007.05.02 (paratype); Agra Arboretum: WHT 6566, 6636, 2238, NMSL uncat. 125-126.

L. dorsicatenatus (4 ex.): Sri Lanka: Nawinna: WHT 6774, 6779; Koskulana, Panapola: WHT 6737, 6745 .

L. megalops (4 ex.): Sri Lanka: Mathale Owilikanda: WHT 6736; Nainakkanda, Wathura: WHT 6729, NMSL uncat. 120; Batadombalena, Kithulgala: NMSL uncat.

L. deignani (3 ex.): Sri Lanka: Kombala-Kottawa Forest Reserve (Hiyare): WHT 6524 (holotype of $L$. greeri), 6525 (paratype of L. greeri); NMSL uncat. (1 ex.).

L. fallax (14 ex.): SriLanka: Pundaluoya: BMNH 1895.723.28c (holotype of L. deraniyagalae); Kandahena Estate: WHT 1579; Puwakpitiya: WHT 2055, NMSL uncat. 9, 11-13 (4 ex.); Mahamewna Uyana: NMSL uncat. 30-31; Polonnaruwa: WHT 6735; Mathale: NMSL uncat. 01; Yala block 01: NMSL uncat. 34; Kitulampitiya, Galle: NMSL uncat. 66; Mahawalatenna, Balangoda: NMSL uncat. 197.

L. taprobanensis (7 ex.): Sri Lanka: Nuwara Eliya (?): BMNH 1946.8.26.11 (syntype); Horton plains: NMSL 2007.22.01-02, WHT 2014, 2097, 2097a-b.

L. merrill (5 ex.): Sri Lanka: Enasalwatte Estate, Sinharaja: NMSL 2011.01.01 (holotype), 2011.01.02, DWC 2011.05.01, 2011.05.02; Mahawalathenna: WHT 6747. 


\section{ERRATUM}

An erratum for the Acknowledgment (page 117, 118), in the article "Kanishka, A.S., A.D. Danushka and A.A.T. Amarasinghe, 2020. A new species of Lankascincus Greer, 1991 (Reptilia: Scincidae) with an overview of the L. gansi group, 9 (1): 103-119 + pls. 37-42”:

The Acknowledgment section must read as follows:

\section{Acknowledgements}

We thank the Department of Wildlife Conservation (Permit no. WL/3/2/81/17) and Department of Forest Conservation (R\&E/RES/NFSRC/2017-04) for granting research permits to Prof. W.A.J.M. de Costa and K.D.B. Ukuwela to carry out National Science Foundation funded tropical forest climate change response project. Habitat data and photographs were taken during the field work of above project by SK and DD. We thank Aaron Bauer (Villanova University, USA), Kanishka Ukuwela (Rajarata University of Sri Lanka), Philip Bowles (IUCN), and an anonymous reviewer for the review of the manuscript and critical comments. Patrick Campbell at BMNH; Nanda Wickramasinghe (former director), Sanuja Kasthuriarachchi (director), Lankani Somaratne, Chamalka Kothalawala, Chandrika Munasinghe, Rasika Dasanayake, Ravindra Wickramanayake, and P. Gunasiri at NMSL are acknowledged for facilitating the in-house study of specimens under their care. Nimalka Sanjeewani, Dilum Samarasingha, Imesh Jayalath, Sampath Senaviratne, Himesh Jayasinghe, Suranjan Karunarathna, Hiranya Sudasinghe, Tharindu Ranasinghe, Divanka Randula, Vimukthi Weeratunga, Nadeeka Hapuarachchi, Madura De Silva and Mendis Wickramasinghe for valuable assistance in numerous stages of the study. We also thank J. Supriatna and the staff of the Research Center for Climate Change, University of Indonesia, for their support.

Erratum published: 28 May 2020 